\title{
Room-Temperature Inelastic Test of a Nozzle-to-Spherical-Shell Model Subjected to Pressure and Moment Loading
}

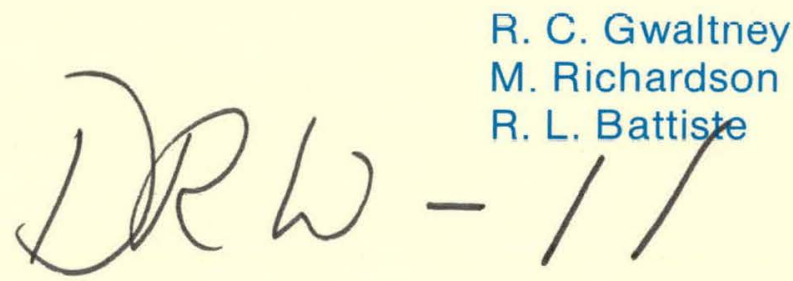

APPLIED TECHNOLOGY

Any further distribution by any holder of this document or of the data therein to third parties representing foreign interests, foreign governments, foreign companies and foreign subsidiaries or foreign divisions of U.S. companies should be coordinated with the Director, Division of Reactor Research and Development, Department of Energy. 


\section{DISCLAIMER}

This report was prepared as an account of work sponsored by an agency of the United States Government. Neither the United States Government nor any agency Thereof, nor any of their employees, makes any warranty, express or implied, or assumes any legal liability or responsibility for the accuracy, completeness, or usefulness of any information, apparatus, product, or process disclosed, or represents that its use would not infringe privately owned rights. Reference herein to any specific commercial product, process, or service by trade name, trademark, manufacturer, or otherwise does not necessarily constitute or imply its endorsement, recommendation, or favoring by the United States Government or any agency thereof. The views and opinions of authors expressed herein do not necessarily state or reflect those of the United States Government or any agency thereof. 


\section{DISCLAIMER}

Portions of this document may be illegible in electronic image products. Images are produced from the best available original document. 


\section{Printed in the United States of America. Available from the Department of Energy, I echnical Intormation Cienter \\ P.O. Box 62, Oak Ridge, Tennessee 37830 \\ Price: Printed Copy $\$ 4.50 ;$ Microfiche $\$ 3.00$}

This report was prepared as an account of work sponsored by an agency of the United States Government. Neither the United States Government nor any agency thereof, nor any of their employees, contractors, subcontractors, or their employees, makes any warranty, express or implied, nor assumes any legal liability or responsibility for any third party's use or the results of such use of any information, apparatus, product or process disclosed in this report, nor represents that its use by such third party would liot infringe privately owned rights. 
ORNL/TM-6170

Dist. Category UC-79, $-79 \mathrm{e},-79 \mathrm{~h},-79 \mathrm{k}$

Contract No. W-7405-eng-26

Engineering Technology Division

ROOM-TEMPERATURE INELASTIC TEST OF A NOZZLE-TO-SPHERICALSHELL MODEL SUBJECTED TO PRESSURE AND MOMENT LOADING

R. C. Gwaltney M. Richardson

R. L. Battiste

NOTICE MN ONLY

PORTIONS OF THIS REPORT ARE ILLEGIBLE. It has been reproduced from the best available copy to permis the broadest possible availability.

Manuscript Completed - February 28, 1978

Date Published - April 1978

Prepared by the

OAK RIDGE NATIONAL LABORATORY

Oak Ridge, Tennessee 37830

operated by

UNION CARBIDE CORPORATION

for the

DEPARTMENT OF ENERGY

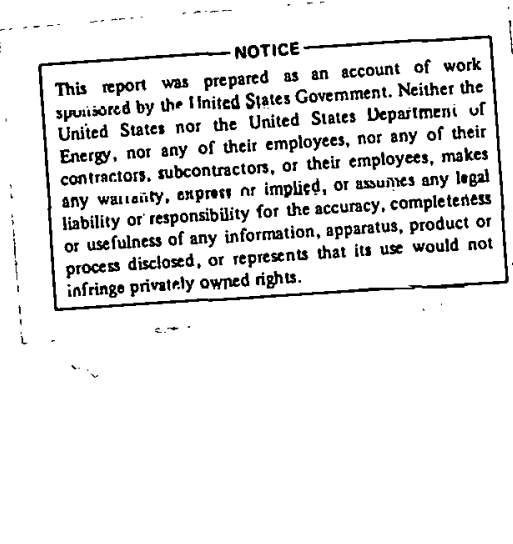

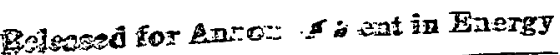

Research A batracts. Oistribntion Limited to Participants in the LMFBR Program. Others request from IIC 
THIS PAGE

\section{WAS INTENTIONALLY \\ LEFT BLANK}


CONTENTS

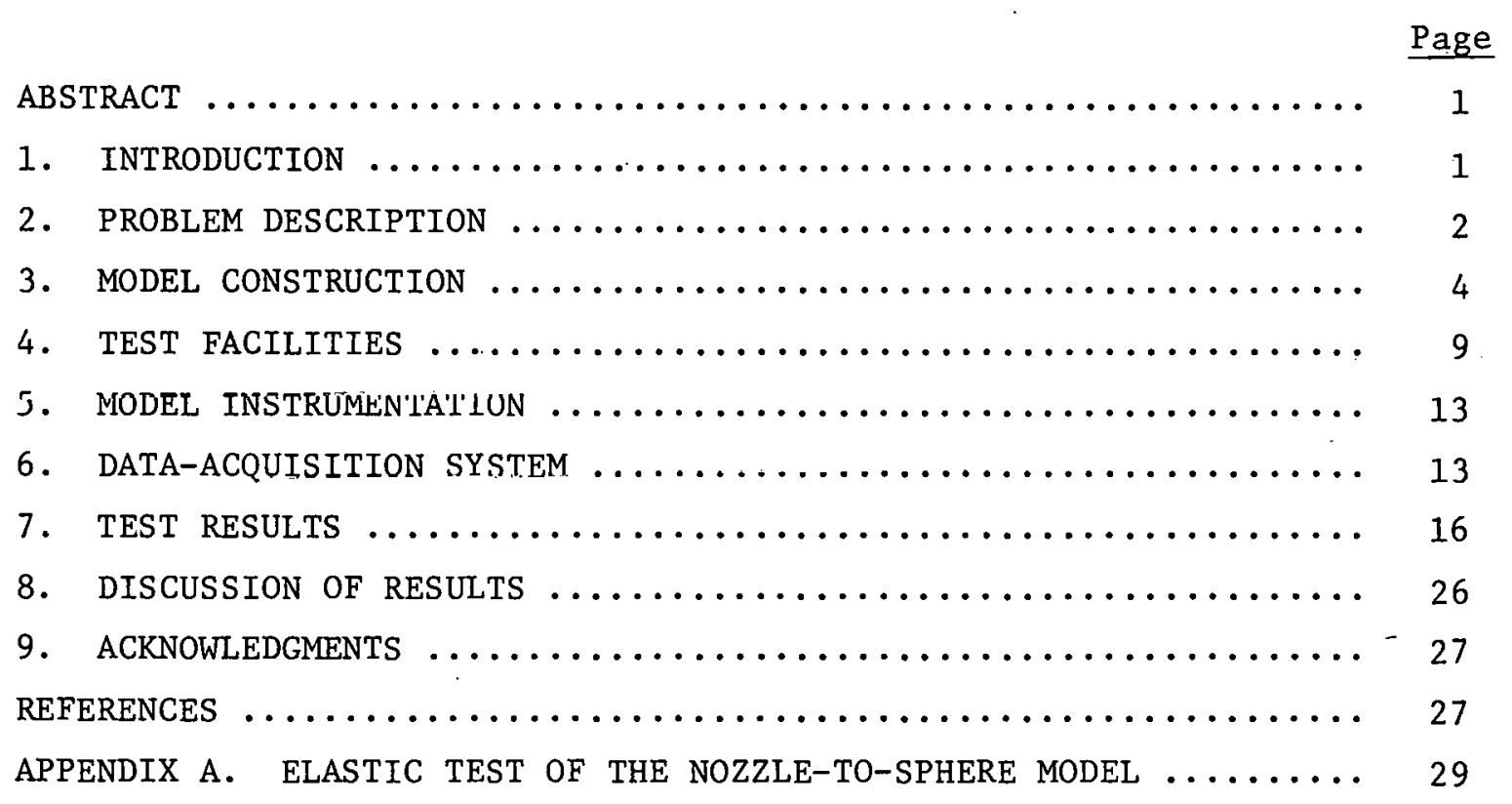


ROOM-TEMPERATURE INELASTIC TEST OF A NOZZLE-TO-SPHERICALSHELL MODEL SUBJECTED TO PRESSURE AND MOMENT LOADING

R. C. Gwaltney M. Richardson

R. L. Battiste

\begin{abstract}
This report presents the measured room-temperature elasticplastic response of a nozzle attached to a spherical shell that was subjected to an internal pressure loading and a cyclic moment applied to the nozzle. The test was performed to qualify the facility and provide experimental benchmark problem data suitable for assessing inelastic analysis methods and validating structural analysis computer programs. The nozzle-to-sphere model is representative of geometries encountered in design because it exhibits the essential features of inelastic behavior of nozzle attachments in pressure vessels. The specimen was machined from a well-characterized heat of type 304 stainless steel, and all tests were performed at a temperature of $21^{\circ} \mathrm{C}$ $\left(70^{\circ} \mathrm{F}\right)$. Test results are presented in terms of loads and strains that typify the overall structural behavior.

Keywords: Plasticity, strain, stress, nozzle, pressure vesse1, experimental, sphere, inelastic, benchmark problems.
\end{abstract}

\title{
1. INTRODUCTION
}

Detailed inelastic analyses may be required in the design of hightemperature reactor system components to demonstrate conformance with design codes and standards. The use of sophisticated computer programs that employ complex constitutive theories and analysis procedures to perform these calculations leads to questions of validation and acceptance of the analysis results. An assessment of analysis predictions can best be made by performing benchmark calculations, that is, by solving a number of carefully chosen structural problems for which experimentally determined response data exist.

In 1969, the U.S. Atomic Energy Commission, predecessor of the Department of Energy, recognized the need for experimental benchmark problem data, particularly at elevated temperatures. To meet this need, the Commission initiated plans for a series of inelastic structural tests on. a variety of etructural gcometrica ranging from simple tu cumplex. 
Initial results from these efforts are presented in Ref. 1. Additional results from simply supported beams and circular plates loaded at the center are presented in Ref. 2. These structural tests are two of the simplest possible for investigating inelastic structural behavior. The more complex structural tests planned include nozzles attached to spherical and cylindrical shells. These structures will be used to study more realistic loading conditions as seen in high-temperature. reactor components.

The test results presented in this report are from a room-temperature elastic-plastic test on a nozzle attached to a spherical shell. The primary rest goal was to qualify the facility for high-temperature testing of the nozzle-to-sphere attachment. During the test the pressurization system did not function as well as planned, and the loadings were not quite satisfactory, leading to modifications of the test factlity. Nonetheless, we believe these results to be useful as a benchmark problem. A preliminary elastic-plastic analysis of the initial inelastic loading of the model was done, ${ }^{3}$. and the results of the theoretical and experimental analyses compared very favorably.

The remainder of this report is divided into nine sections. Section 2 describes the nozzle-sphere model and presents the loading histograms and test parameters for the test. Section 3 describes the model mantfacture and material. The test facilities and procedures are described in Section 4; the model instrumentation is discussed in Section 5 and the data-acquisition system in Section 6. Finally, representative test results for the test are presented in Section 7 , and the results are discussed in Section 8.

Appendix A contains a summary of the elastic test of the nozzle-toophere model which was done to verify that the loading mechanism functioned correctly. Comparisons between experimental and analytical results confirmed the correct functioning of the loading mechanism.

\section{PROBLEM DESCRIPTION}

The nozzle-to-spherical-shell model is depicted in Fig. 1; the dimensions are shown. The sphere has an inside radius of $0.308 \mathrm{~m}$ (12.14 in.) 


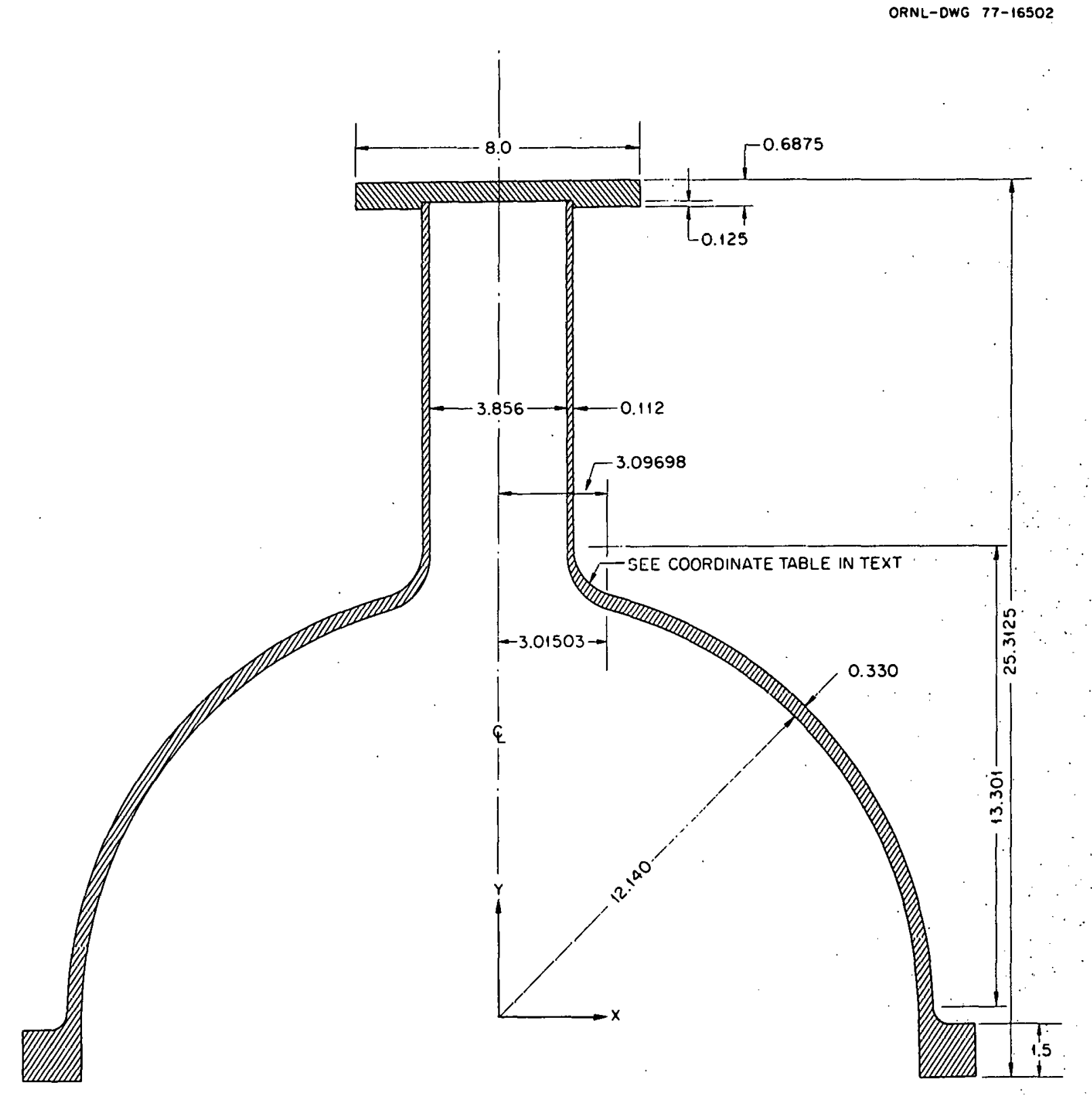

NOTE:

DIMENSIONS ARE IN INCHES

Fig. 1. Nozzle-to-sphere model. Dimensions are in inches ( 1 in. $=$ $\left.2.54 \times 10^{-2} \mathrm{~m}\right)$. 
with a wall thickness of $8.38 \mathrm{~mm}$ ( $0.330 \mathrm{in.}$ ); the nozzle has an inside diameter of $9.79 \mathrm{~cm}$ (3.856 in.) with a wall thickness of $2.85 \mathrm{~mm}(0.112$ in.). A toroidal transition or fillet with a variable wall thickness joins the nozzle to the sphere (see Fig. 1). Table 1 lists the $x$ and $y$ coordinates of the transition region of the model.

Figure 2 depicts the actual measured histograms used for the test. The numbers shown on the histograms are for reference purposes. Specific pressure and moment values for several points are listed in Table 2 . All major load changes shown in Fig. 2 were ramp shaped; the loading rate for prossure was $3.45 \mathrm{MPa}(500 \mathrm{psi})$ in $30 \mathrm{sec}$ and, for the moment, was hased on a 2-min cycle (30 sec per quarter cycle, such as points 16 to 17). The odd shape of the pressure histogram was caused by the malfunction of the pressure control system: The feedback system was working incorrectly in that the planned test pressures $[3.45 \mathrm{MPa}$ (500 psi) on the first load and $5.52 \mathrm{MPa}$ (800 psi) on the second] were never reached inside the model even though the load cells and pressure gages indicated the planned pressures were reached. After loading, the feedback system kept trying to reach the planned internal pressure, thus slowly increasing the internal pressure during the test. Upon depressurization, the internal pressure was not reduced to zero because of the malfunctioning feedback system. After the test was completed, the pressure histogram wao dcveloped from strain data taken in the membrane region of the nozzle.

The loading histories depicted in Fig. 2 and delineated in Table 2 were contrived to study the inelastic behaviur of a liuzzle to spherc subjected to internal pressure and cyclic moment loads applied to the nozzle. The test also allowed checkout of Llie luzzle-to-sphcrc tecting facility to ensure that it functioned correctly before the high-temperature tests of the nozzle-to-sphere models (see Appendix A).

\section{MODEL CONSTRUCIION}

One of the primary objectives of the experimental analys 1s described in this report was to obtain experimental data on a carefully machined nozzle-to-sphere model to minimize the effects of geometric imperfections. 
Table 1. Coordinates of the transition region ${ }^{a}$

\begin{tabular}{|c|c|c|c|}
\hline \multicolumn{4}{|c|}{ Coordinate table } \\
\hline \multicolumn{2}{|c|}{ Inside } & \multicolumn{2}{|c|}{ Outside } \\
\hline$+x$ & ty & $+x$ & $+y$ \\
\hline $\begin{array}{l}3.01503 \\
2.962 .55\end{array}$ & $\begin{array}{l}11.75964 \\
11.77705\end{array}$ & $\begin{array}{l}3.09698 \\
3.05394\end{array}$ & $\begin{array}{l}12.07930 \\
12.08817\end{array}$ \\
\hline 2.91080 & 11.79623 & 3.01114 & 12.09855 \\
\hline 2.85985 & 11.81717 & 2.96862 & 12.11044 \\
\hline $\begin{array}{l}2.80975 \\
2.76055\end{array}$ & $\begin{array}{l}11.83983 \\
11.86418\end{array}$ & $\begin{array}{l}2.92646 \\
2.88469\end{array}$ & $\begin{array}{l}12.12384 \\
12.13873\end{array}$ \\
\hline 2.71232 & 11.89018 & 2.84338 & 12.15511 \\
\hline 2.66511 & 11.91779 & 2.80257 & 12.17296 \\
\hline 2.61898 & 11.94697 & 2.76231 & 12.19227 \\
\hline 2.57 .397 & 11.97769 & 2.72267 & 12.21301 \\
\hline 2.53013 & 12.00989 & 2.68369 & 12.23517 \\
\hline 2.48753 & 12.04355 & 2.64542 & 12.25873 \\
\hline 2.44620 . & 12.07860 & 2.60791 & 12.28366 \\
\hline 2.40618 & 12.11500 & 2.57122 & 12.30994 \\
\hline 2.36753 & 12.15270 & 2.53538 & 12.33755 \\
\hline 2.33029 & 12.19166 & 2.50045 & 12.36646 \\
\hline 2.29449 & 12.23181 & 2.46648 & 12.39663 \\
\hline 2.26017 & 12.27311 & 2.43350 & 12.42803 \\
\hline 2.22738 & 12.31550 & 2.40157 & 12.46064 \\
\hline 2.19613 & 12.35893 & 2.37073 & 12.49441 \\
\hline 2.16648 & 12.40333 & 2.34103 & 12.52932 \\
\hline 2.13844 & 12.44866 & 2.31249 & 12.56531 \\
\hline 2.11205 & 12.49485 & 2.28517 & 12.60236 \\
\hline 2.08732 & 12.54184 & 2.25910 & 12.64042 \\
\hline 2.06430 & 12.58958 & 2.23432 & 12.67945 \\
\hline 2.04298 & 12.6 .3800 & 2. 21087 & 12.71941 \\
\hline 2.02341 & 12.68703 & 2.18877 & 12.76024 \\
\hline 2.00559 & 12.73663 & 2.16807 & 12.80191 \\
\hline 1.98953 & 12.78672 & 2.14879 & 12.84437 \\
\hline 1.97526 & 12.83725 & 2.13096 & 12.88757 \\
\hline 1.96278 & 12.88814 & 2.11462 & 12.93145 \\
\hline 1.95210 & 12.93935 & 2.09979 & 12.97598 \\
\hline 1.9432 .3 & 12.99079 & 2.08648 & 13.02108 \\
\hline 1.93617 & 13.04241 & 2.07474 & 13.06672 \\
\hline 1.93092 & 1.3 .09415 & 2.06457 & 13.11284 \\
\hline 1.92800 & 13.14594 & 2.05599 & 13.15938 \\
\hline 1.92800 & 13.19772 & 2.04903 & 13.20629 \\
\hline 1.92800 & 13.24943 & 2.04369 & 13.25352 \\
\hline 1.92800 & 13.30100 & 2.04000 & 13.30100 \\
\hline
\end{tabular}

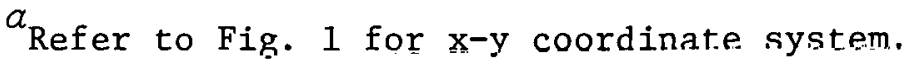


ORNL--UNG 78- 2877
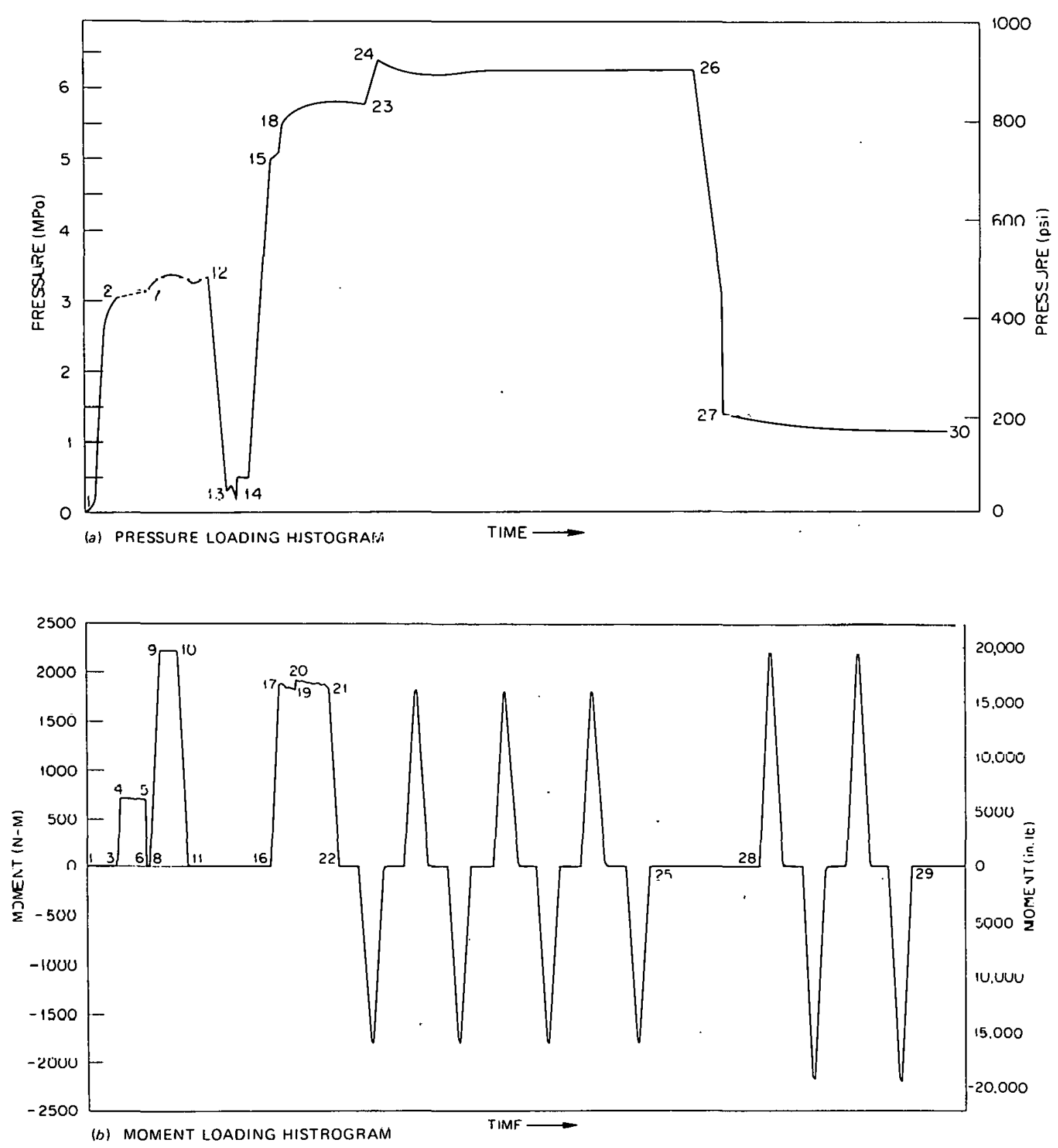

Fig. 2. Histograms for the nozzle-to-sphere test. (a) Pressure loading histogram; (b) moment loading histogram. 
Table 2. Pressure and moment loading for selected reference points of the histograms in Fig. 2

\begin{tabular}{|c|c|c|}
\hline $\begin{array}{c}\text { Reference } \\
\text { point }\end{array}$ & $\begin{array}{l}\text { Pressure } \\
{[\mathrm{MPa}(\mathrm{psi})]}\end{array}$ & Moment $[\mathrm{N}-\mathrm{m}$ (in. $-1 \mathrm{~b})]$ \\
\hline 1 & 0 & 0 \\
\hline 2 & $3.0 \quad(435)$ & 0 \\
\hline 4 & $3.0(435)$ & $719(6360)$ \\
\hline 5 & $3.25(471)$ & $719(6360)$ \\
\hline 7 & $3.25(471)$ & \\
\hline 9 & $3.33(483)$ & $2234(19,773)$ \\
\hline 12 & 3.35 (486) & 0 \\
\hline 13 & $0.29(43)$ & 0 \\
\hline 14 & $0.5(73)$ & 0 \\
\hline 15 & $5.0(725)$ & 0 \\
\hline 18 & $5.5(798)$ & $1875(16,593)$ \\
\hline 21 & $5.82(845)$ & $1859(16,455)$ \\
\hline 23 & $5.82(845)$ & $1844(16,316)^{a}$ \\
\hline 24 & $6.35(921)$ & $1844(16,316)^{a}$ \\
\hline 26 & 6.27 (909) & 0 \\
\hline 27 & 1.41 (204) & 0 \\
\hline 28 & 1.35 (196) & $2234(19,773)^{b}$ \\
\hline 29 & 1.19 (173) & 0 \\
\hline 30 & $1.15(166)$ & 0 \\
\hline \multicolumn{3}{|c|}{$\begin{array}{l}\text { a Between points } 22 \text { and } 25 \text {, three and one-half } \\
\text { complete moment cycles were applied to the model. } \\
b_{\text {Between points } 28 \text { and } 29 \text {, two complete moment }} \\
\text { cycles were applied to the model. }\end{array}$} \\
\hline
\end{tabular}

The basic configuration was obtained by using a thick preformed spherical forging made of reference heat type 304 stainless steel (9T2796). The attached nozzle was machined from heavy-walled pipe of the same reference heat. Figure 3 shows the model after the initial exterior rough machining of the forging prior to welding on of the nozzle. Note that the fillet region has been rough machined on the spherical forging. After the heavy-walled pipe nozzle was welded on the model, the model was annealed to remove the resulting residual stresses. The model was subjected to a full anneal $\left[1093^{\circ} \mathrm{C}\left(2000^{\circ} \mathrm{F}\right)\right.$ for $30 \mathrm{~min}$ ] followed by a rapid forced-air cooling to room temperature. The model was again rough machined to approximately the final dimensions; machining to the final dimensions was then completed by taking small cuts. A11 


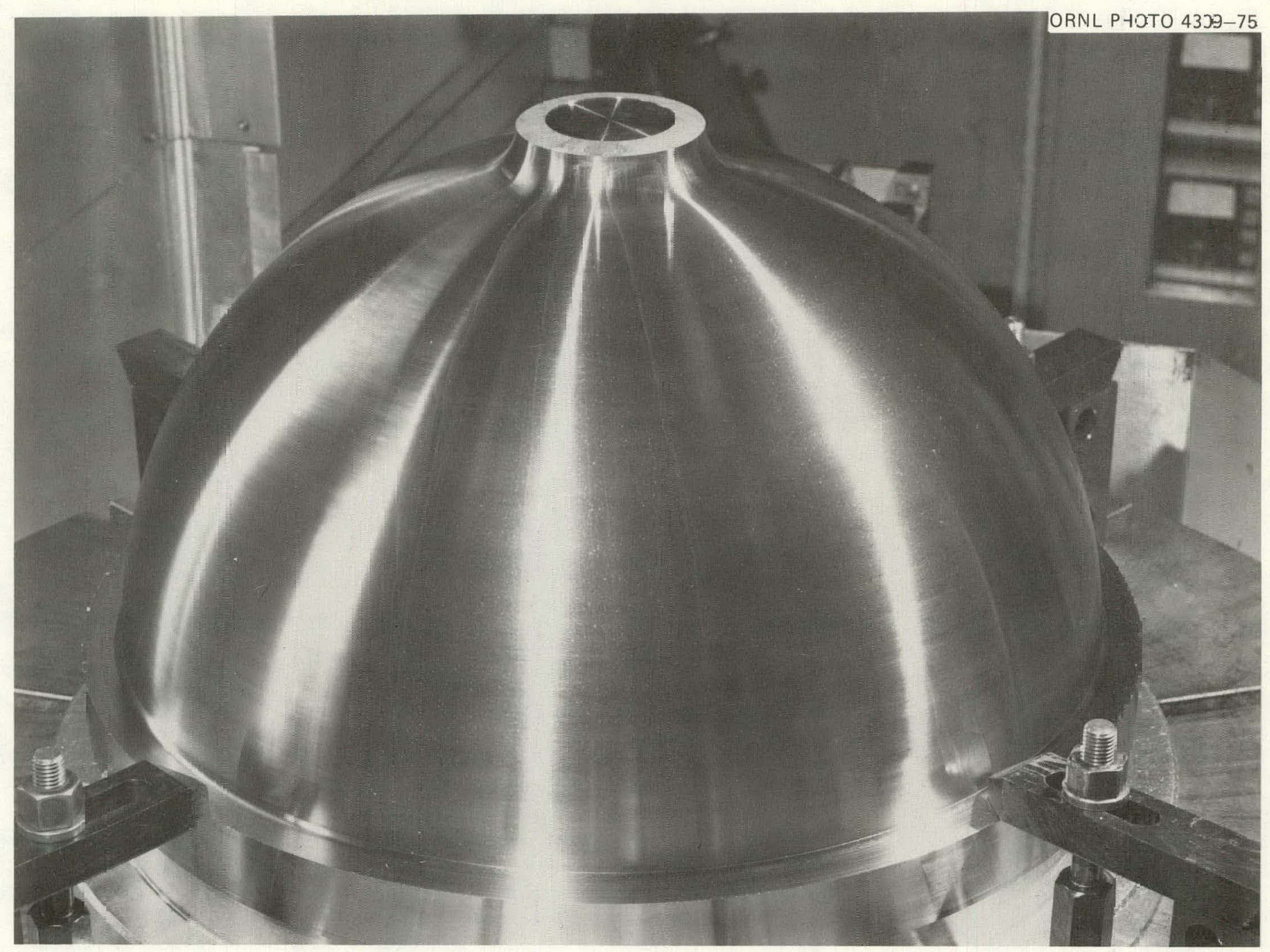

Fig. 3. Sphere for nozzle-to-spherical-shell model after initial rough rachining of the forging. 
the machining of the model was done on an automatic tape-controlled boring mill. The completed model is shown in Fig. 4.

\section{TEST FACILITIES}

A special elevated-temperature test facility was specifically designed and built to test nozzle-to-spherical shell configurations and to subject them to an internal pressure and a time-varying moment applied to the nozzle at temperatures up to $593^{\circ} \mathrm{C}\left(1100^{\circ} \mathrm{F}\right)$.

Figure 5 shows the instrumented model in the loading frame with a moment load being applied to the nozzle; a schematic diagram of the loading facility is shown in Fig. 6, illustrating that the pressure is contained within the annular space provided between the shaped internal shell of the support structure and the model wall. The model is installed over the internal shell and clamped to the top flange of the support structure by means of a matching slip-on flange. The pressure seal for the room-temperature test was made using a flat neoprene 0-ring gasket placed between the bearing surfaces. The annular space was made large enough to permit installation of internal strain gages and thermocouples. A shaped-graphite insert was fabricated to reduce the volume of the annular space to approximately $6.35 \mathrm{~mm}$ (0.25 in.) radial clearance between the graphite and the internal model wall in case internal instrumentation is not required.

The external moment is applied to the nozzle by means of a special flanged shaft adapter which is attached to the nozzle and normal to it (see Fig. 6). Torque is transmitted to the shaft through a modified double universal joint with a sliding ball spline driven by the actuator mechanism. The special joint is used to transmit pure torque with no bending, and the facility is designed for a maximum torque of $2260 \mathrm{~N}-\mathrm{m}$ $(20,000$ in.-1b). The actuator arm is driven by a programmable, servocontrolled, double-acting hydraulically driven ram to which the load trays are chain-connected as shown in Fig. 6 .

An independent, programmable, closed-loop gas pressurization system (nitrogen) is incorporated in the facility for applying internal pressure to the model at the rale needed for the test. For the room-temperature 


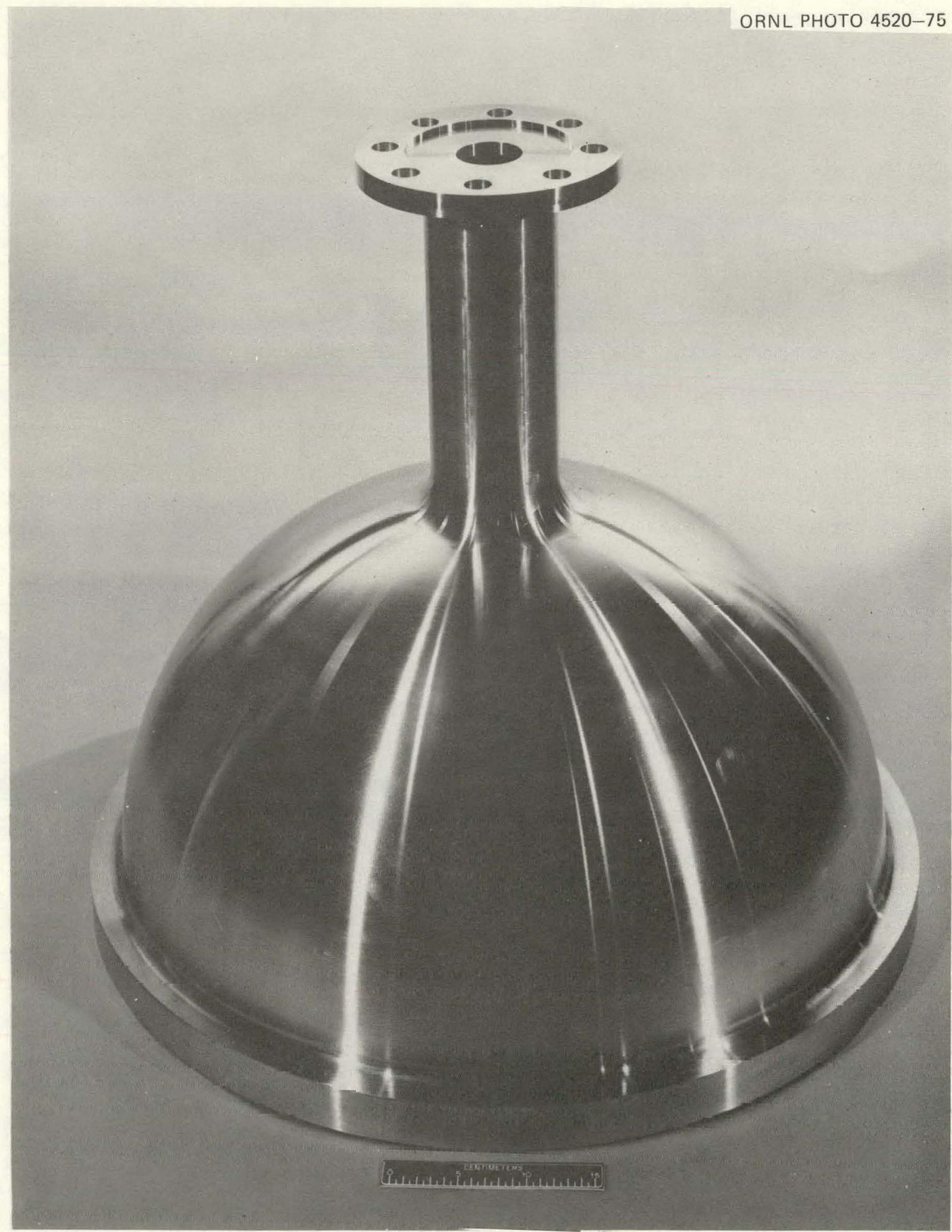

Fig. 4. Finished nozzle-to-spherical-shell model. 


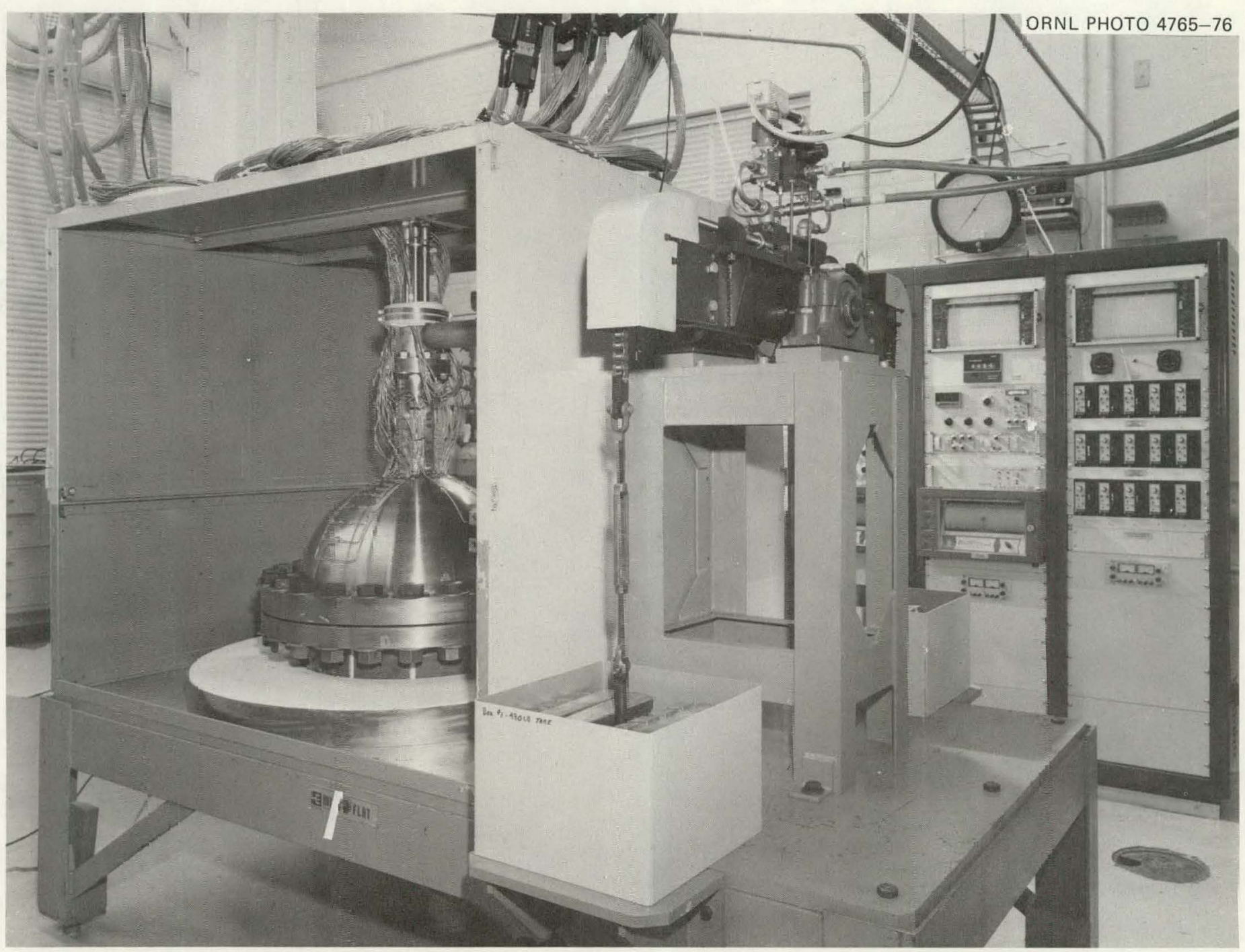

Fig. 5. Instrumented model in the test facility with a moment being apfiec to the nczzle. 


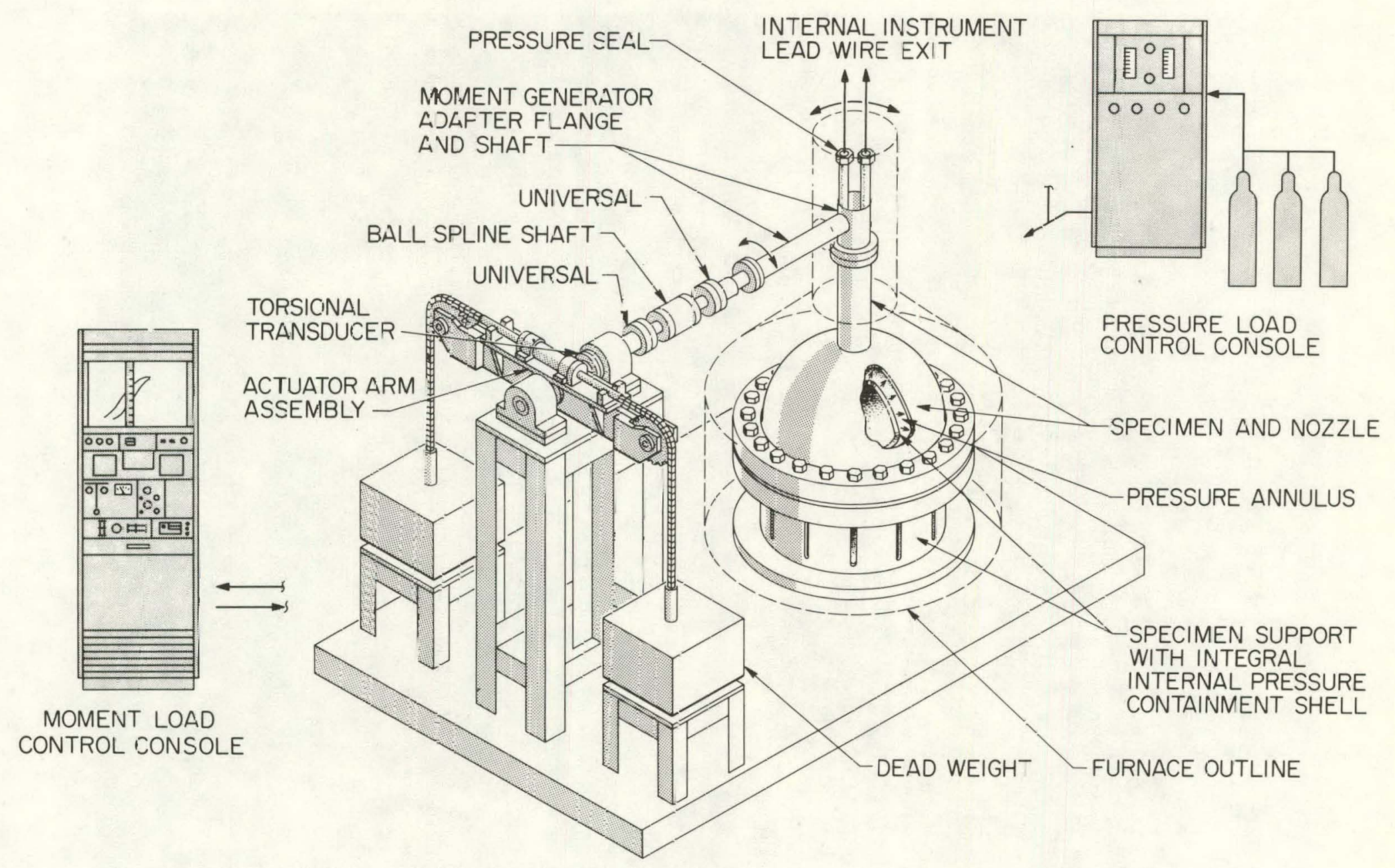

Fig. 6. Conceptual sketch of the nozzle-to-sphere test facility. 
elastic-plastic test, this system was modified by filling the pressure annulus of the model with oil and applying gas overpressure to the oil reservoir by means of the gas pressure controller. As pointed out earlier, the pressure feedback system was operating incorrectly and the pressures never reached the planned values.

\section{MODEL INSTRUMENTATION}

The strain gages used for this test were Micro-Measurements type EA-06-030YB-120. The gages are miniature three-element Y-delta single plane rosettes with a $120-\Omega$ resistance and a 2.07 gage factor.

The model was instrumented with strain gages on both the inside and outside surfaces as shown in Fig. 7. A total of 82 rosettes was used with 46 of these on the outside surface and 36 on the inside surface; they were located radially opposite or back to back in all cases.

The gages were arranged along four lines running in the meridional direction. Along the gage lines marked north $(\mathrm{N})$ and south (S) (see Fig. 7), there were 18 rosettes both inside and outside for a total of 36 rosettes along each line. Along the lines marked east (E) and west (W), there were 5 rosettes each on the outside surface (see Fig. 7, locations $1,6,8,10$, and 16).

The rosettes were applied with an adhesive, MM-200 bond, which is available from Micro-Measurements, Inc. Uninsulated 4-mil-diam wire was used to connect the gages with the terminal tabs, which were connected with larger lead wires. The strain-gage data were recorded by a Datum Computer-Controlled Data-Acquisition System.

The inside surface of the model is shown in Fig. 8 with the gages applied and completely wired. The north and south gage lines can be clearly seen.

\section{DATA-ACQUISITION SYSTEM}

The strain-gage data were recorded by a Datum Computer-Controlled Data-Acquisition System (CCDAS). The system consists of a data-acquisition unit composed of a control module controlled by a PDP-8/I computer with 


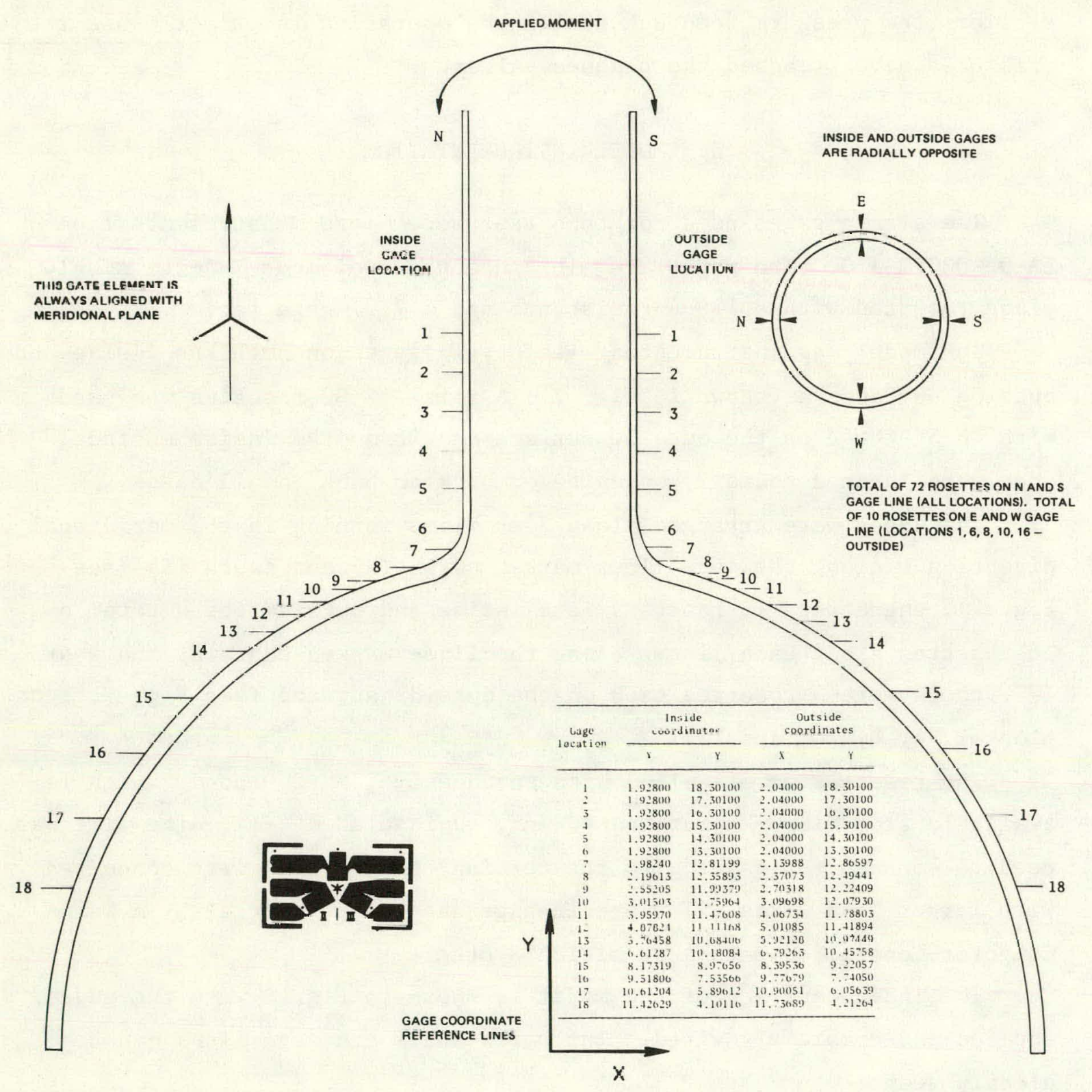

Fig. 7. Gage positions for the model used in the test. 


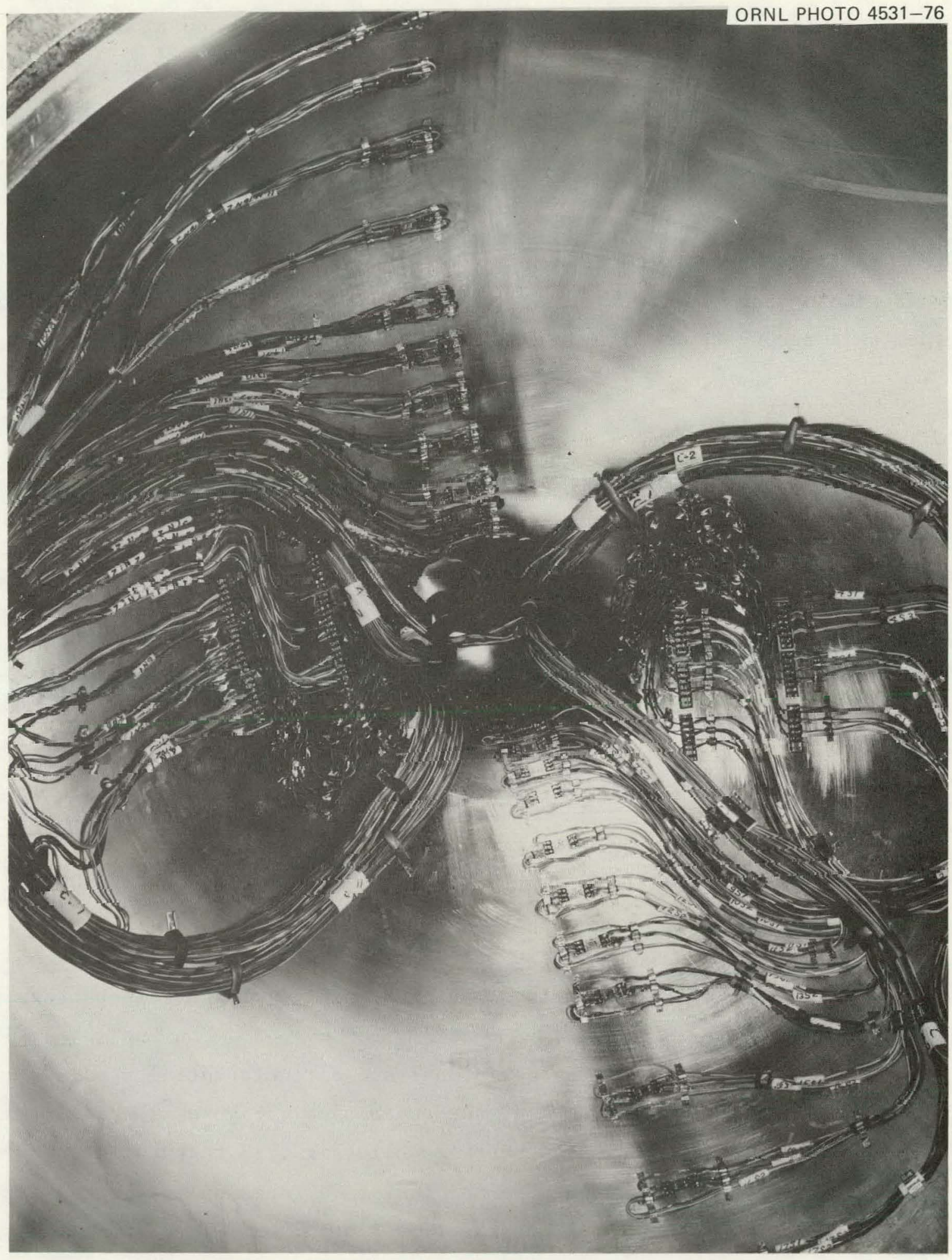

Fig. 8. Inside surface of model during instrumentation. 
the following capabilities: (1) magnetic tape input/output system, (2) in-core calculation ability, (3) teletypewriter input and output, and (4) signal conditioning and self-calibration of the gages.

For this test, the system was programmed to read at a rate of 500 gages per second and record the readings for all gages ( 82 rosettes) at a rate of once per second. The system records the strain data in millivolt readings on magnetic tape. The PDP-8/I computer converts the millivolt readings on the tape into engineering units (strains) and stores them on a second tape which is compatible with the ORNL TBM/360 computers.

\section{TEST RESULTS}

Typical test results are presented in this section, where strains are shown as functions of the applied loads. Data were taken for all 82 rosettes, and 1734 data points were taken for each gage. In all, 426,564 data points were taken during the test. Of the 82 rosettes on the model, 4 were chosen as being of particular importance and representative of the inelastic response of the model to the applied loads.

The rosettes chusen arc shown in Fig. 7 as location 8 on both the north and south sides and on the inside and outside surfaces. These roscttes are in the midule of the transition region and are near the points of maximum strain.

The loading of the model is complex (see Fig. 2) in that on the south side Llie effcct of a pnsitive moment is additive to the pressure effect while a negalive moment is suhtractive. The opposite is true on the north side. The combined loading leads to a complex strain pattern, as will be seen in the figures.

Figures 9 and 10 show the meridional and circumferential strain response on the outside surface of the south side. Figures $1 \perp$ and 12 show the response on the inside surface while Figs. 13 through 16 show the strain response on the outside and inside surfaces on the north side. These strain responses are all at gage location 8 .

In Figs. 9 through 12, the response to the first pressurization is linear [3.0 $\mathrm{MPa}$ (435 psi)] (see points 1 and 2 in the figures). The first response to the moment loading [719 $\mathrm{N}-\mathrm{m}$ (6360 in.-1b)] was also 
ORNL -DWG 78 -2878
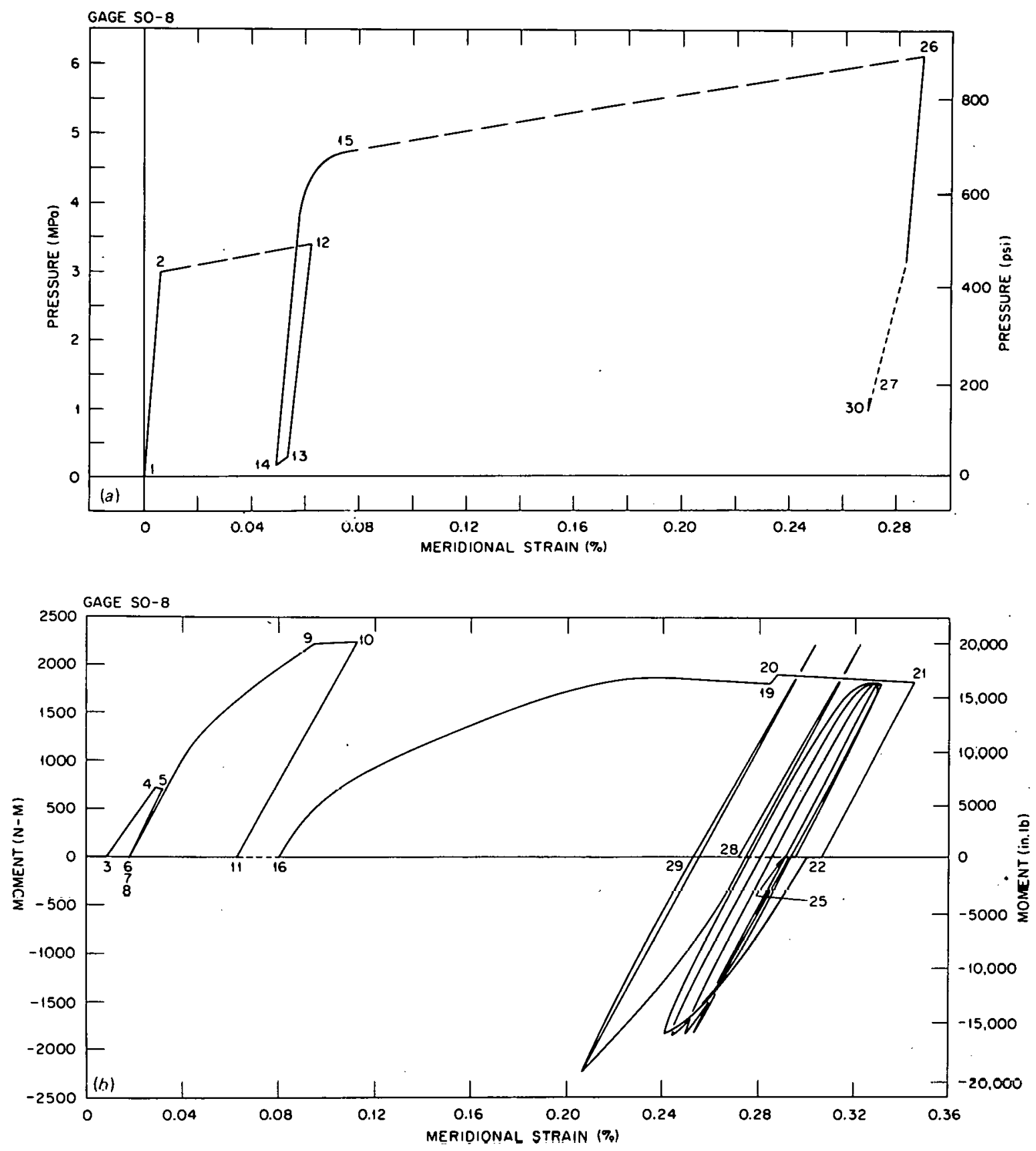

Fig. 9. Meridional strain response at gage location 8 on the south outside surface. (Dashed curves indicate unresolved data between these points.) 
ORNL DWG 782879
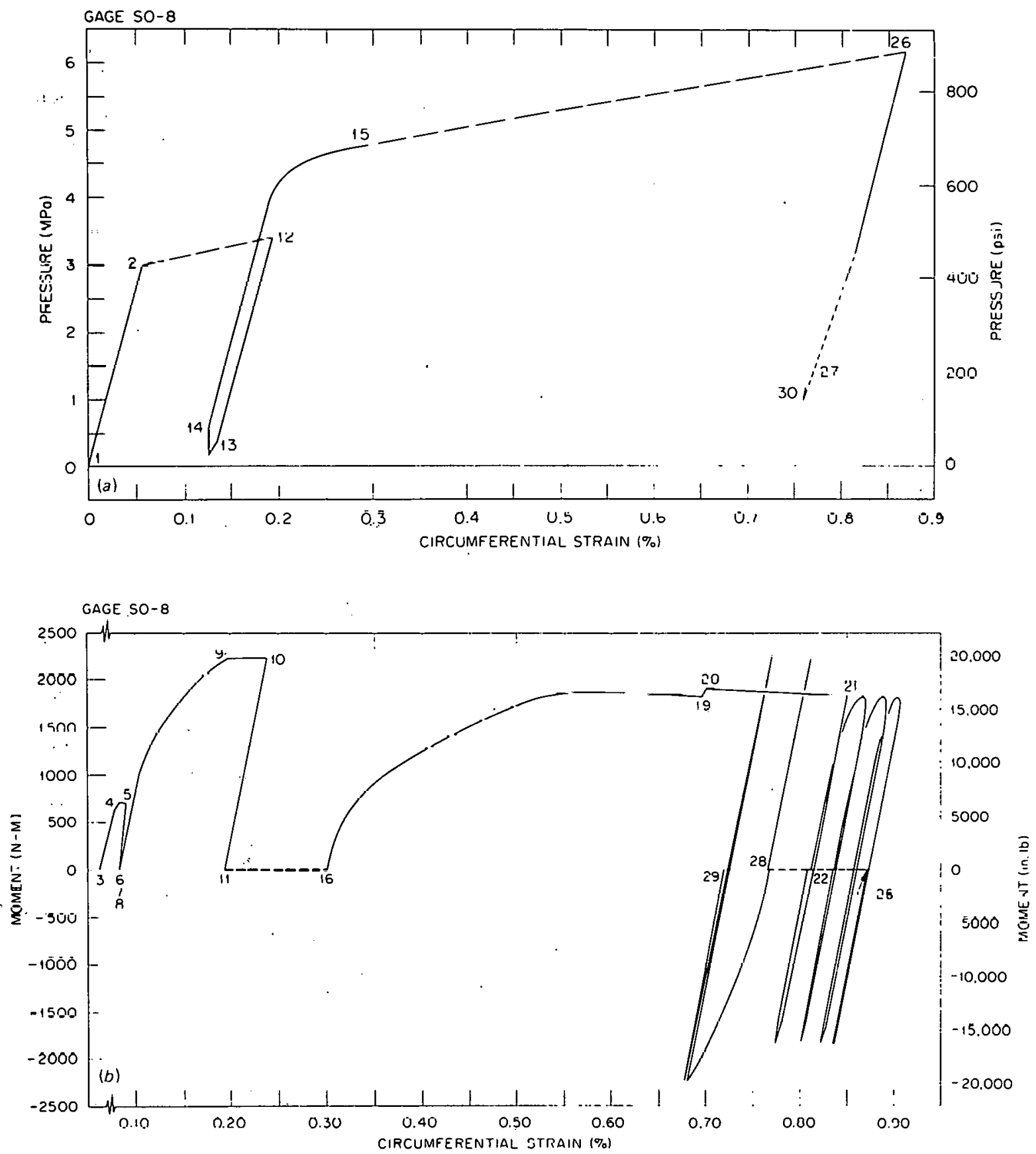

Fig. 10. Circumferential strain response at gage location 8 on the south outside surface. (Dashed curves indicate unresolved data between these points.) 

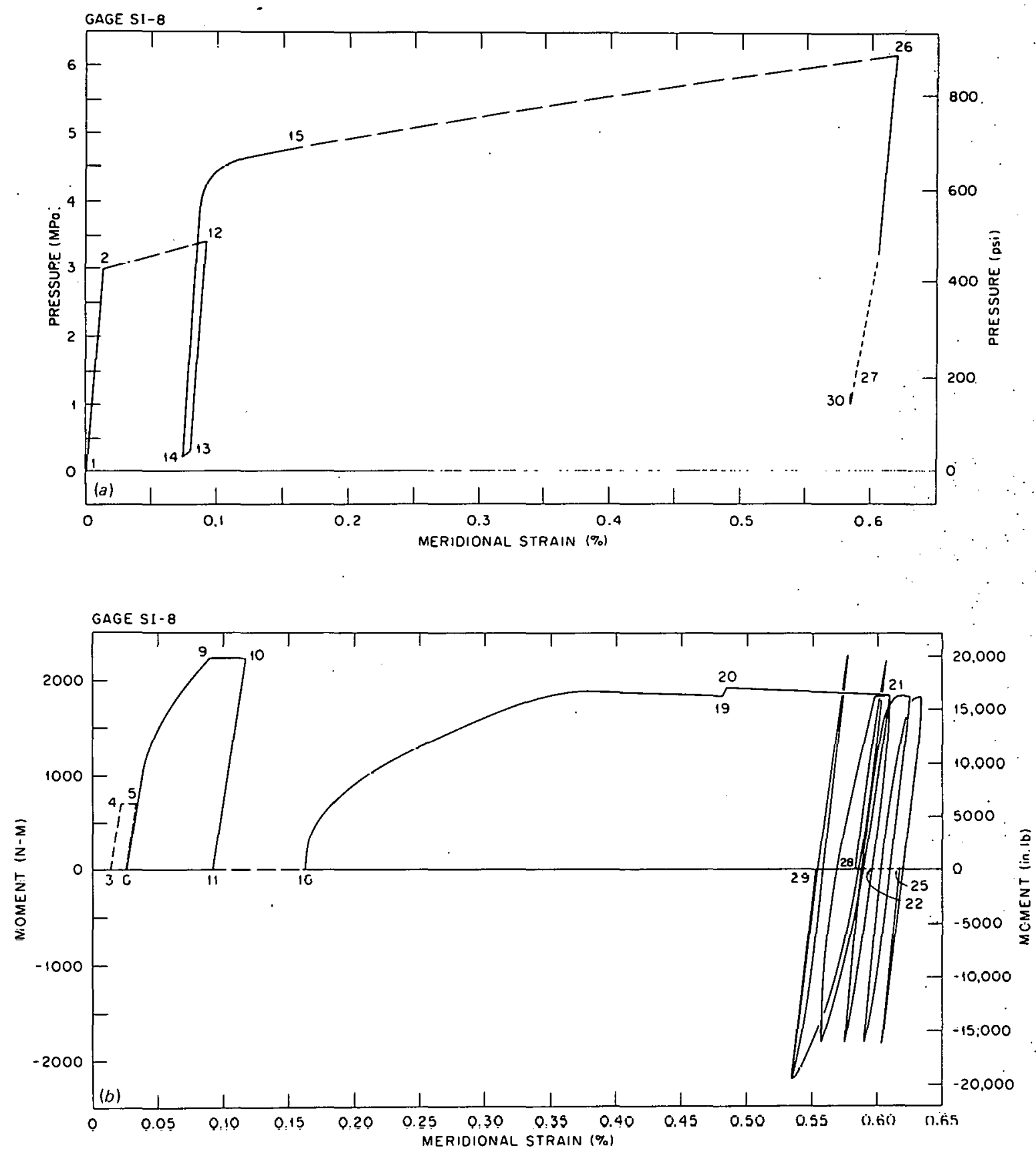

Fig. 11. Meridional strain response at gage location 8 on the south inside surface. (Dashed curves indicate unresolved data between these points.) 

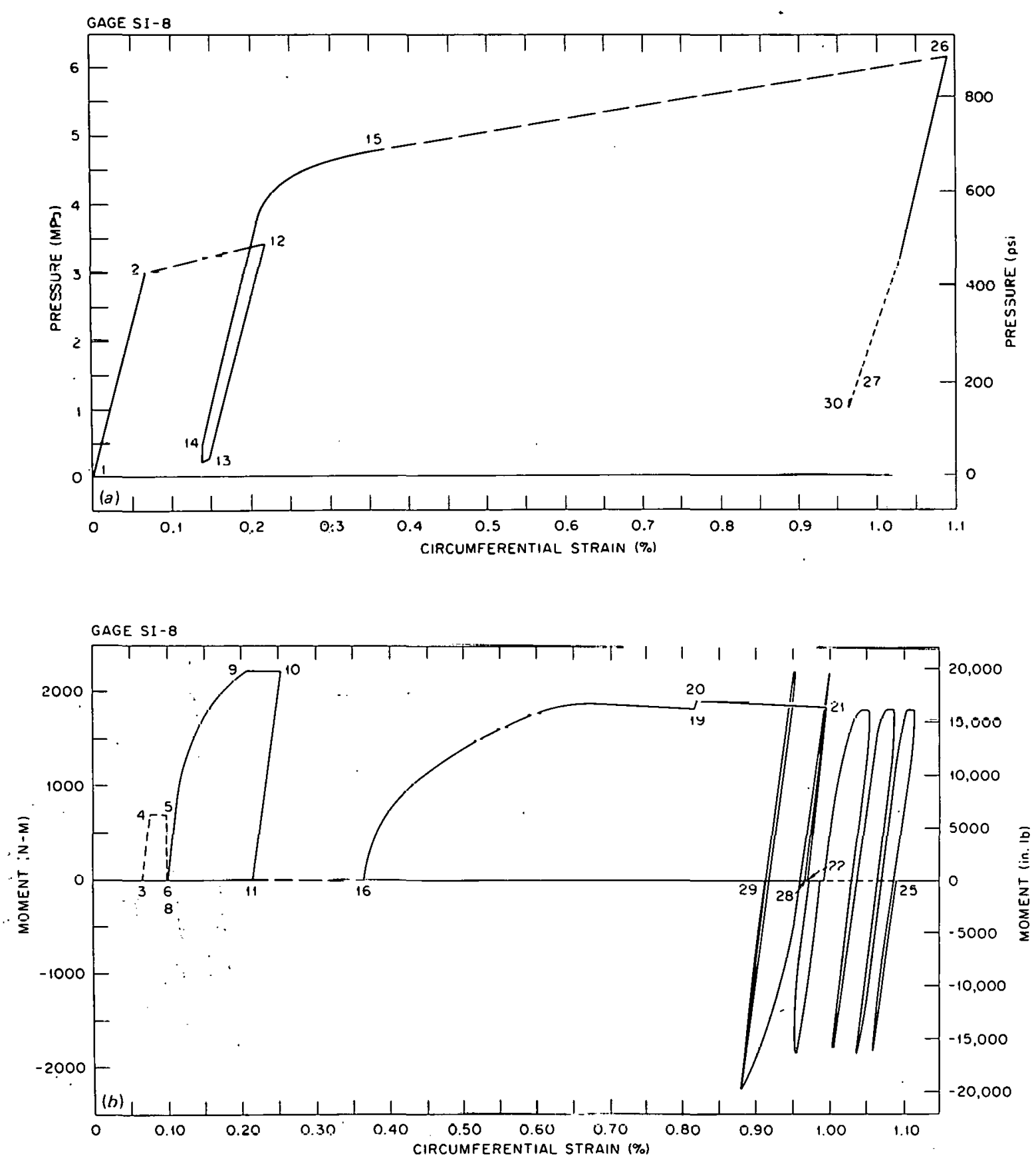

Fig. 12. Circumferential strain response at gage location 8 on the south inside surface. (Dashed curves indicate unresolved data between these points.) 

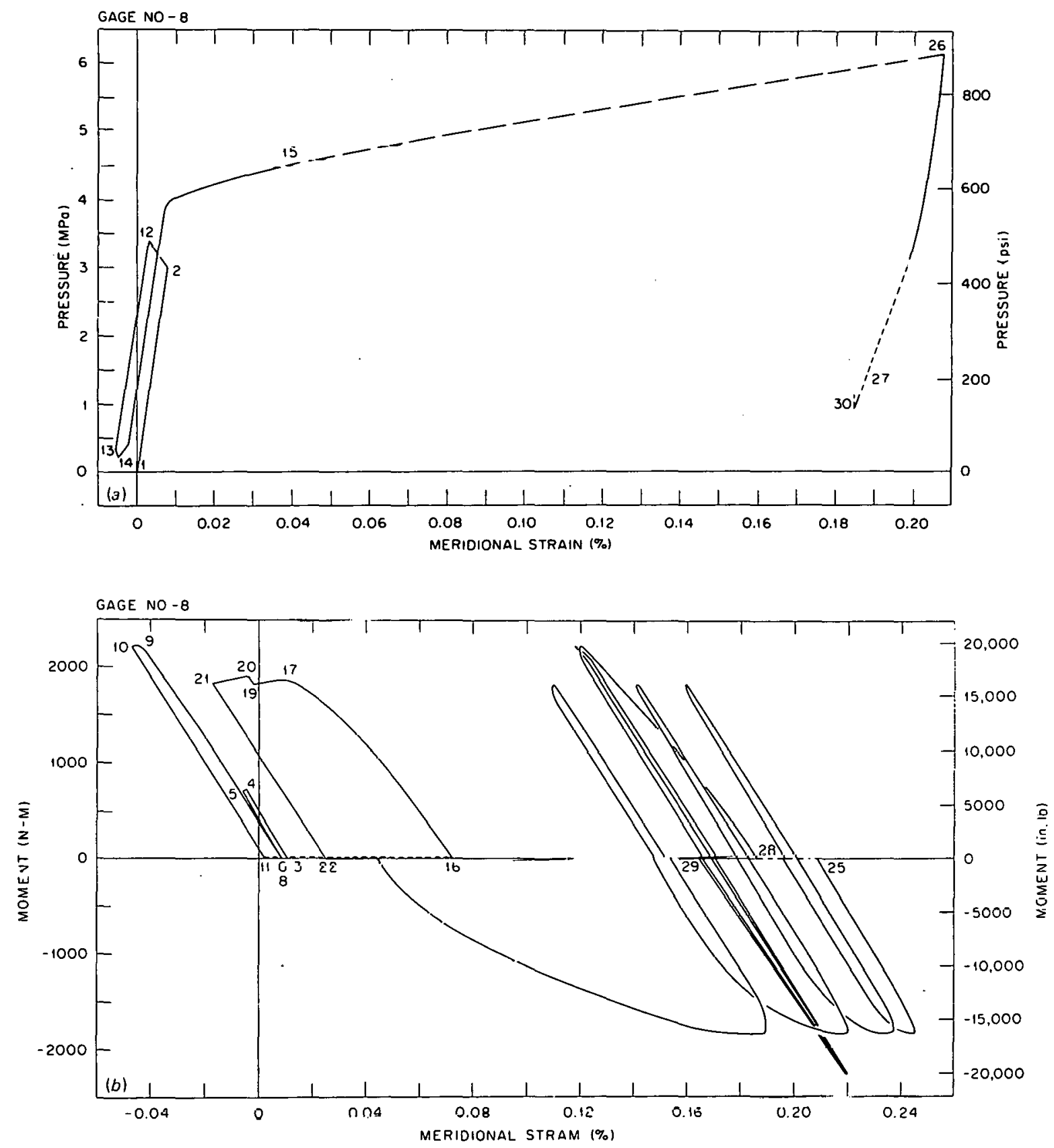

Fig. 13. Meridional strain response at gage location 8 on the north outside surface. (Dashed curves indicate unresolved data between these points.) 
ORNL - DWG 78-2883
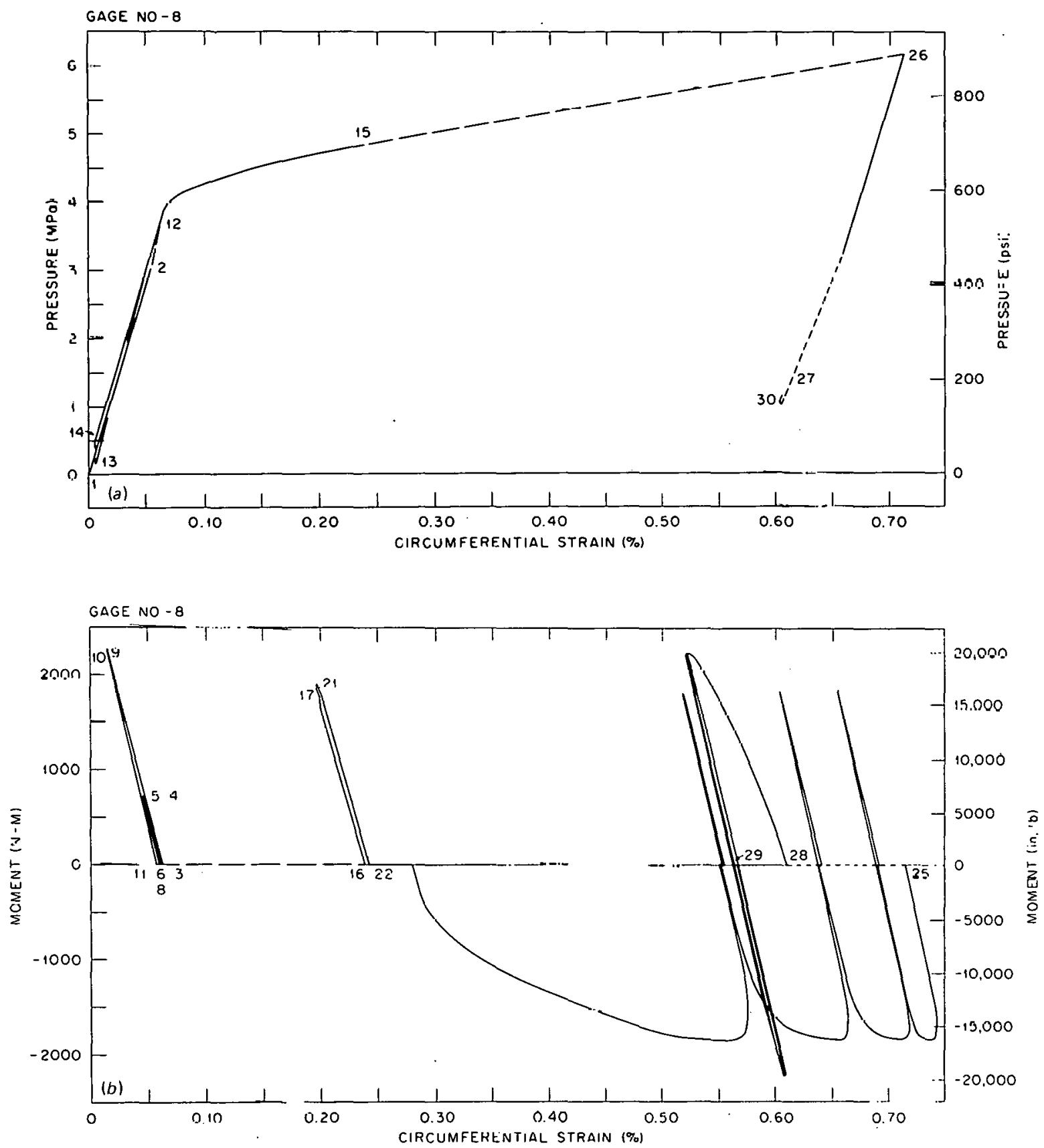

Fig. 14. Circumferential strain response at gage localion 8 on the north outside surface. (Dashed curves indicate an unresolved path between these points.) 
ORNL. DWG 78- 2884
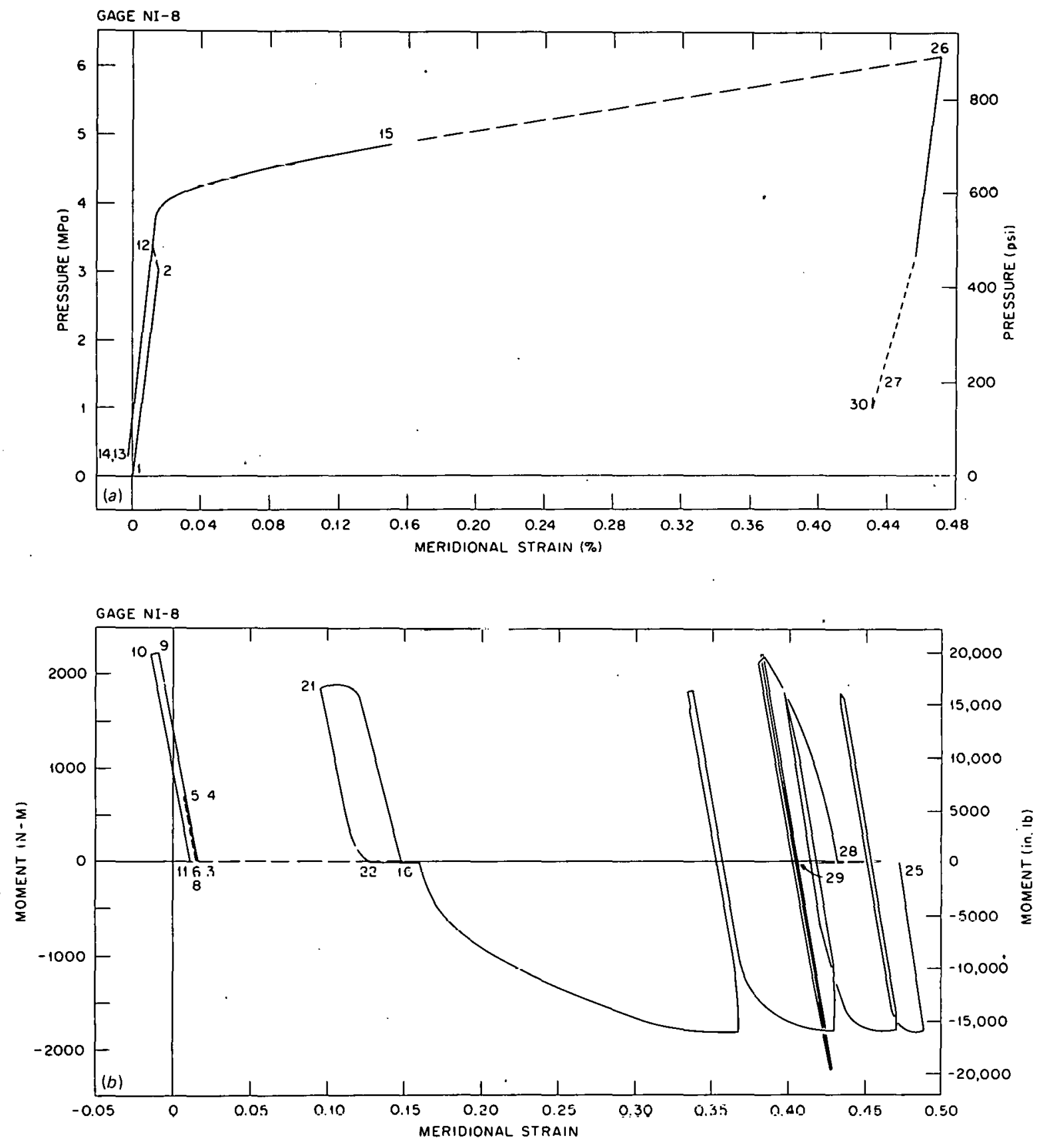

Fig. 15. Meridional strain response at gage location 8 on the north inside surface. (Dashed curves indicate unknown data between these points.) 
ORNL-DWG $78 \cdots 2885$
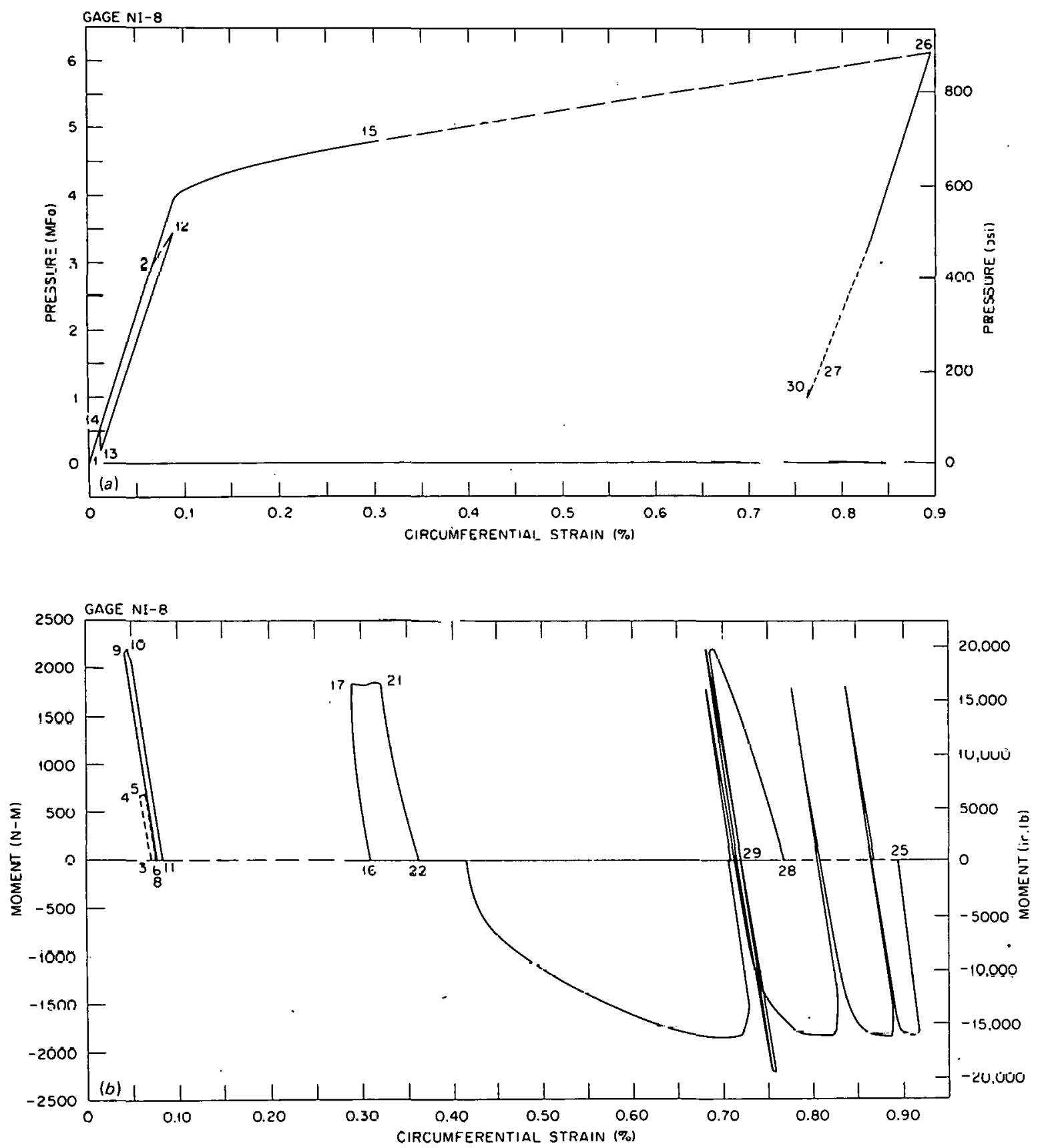

Fig. 16. C1rcumferential strain response at gage location 8 on the north inside surface. (Dashed curves indicate unresolved data between these points.) 
linear (see points 3 through 6 in the figures). The next moment loading [2234 N-m (19,773 in.-1b)] produced an elastic-plastic response during loadup (see points 8 through 11 in the figures). The flat tops on the first two moment-strain curves were caused by the slowly increasing pressure between points 2 and 12 as shown in Fig. 2 (dashed curve indicates unknown path). The depressurization from $3.35 \mathrm{MPa}$ (486 psi) to $0.29 \mathrm{MPa}$ (43 psi) produced a linear response as shown by points 1.2 to 13 in the figures. Note that the pressure did not reduce to zero due to the discussed malfunction of the pressure control system.

The second pressurization to $5.0 \mathrm{MPa}$ ( $725 \mathrm{psi}$ ) produced an elasticplastic response (points 14 to 15 ). The initial step of the first cyclic moment of $\pm 1875 \mathrm{~N}-\mathrm{m}(16,593$ in.-1b) generated a great deal of plastic response as seen in the figures (points 16 through 22). The portion of the moment-strain curve which shows an increasing strain without an increase in moment is caused by the slowly increasing pressure between points 15 and 23 as shown in Fig. 2. The next 3.5 moment cycles are shown in the figures between points 22 and 25 . As can be seen, the structure tended to shake down under this cyclic moment loading. The momentstrain cycles tended to become smaller as the number of the cycles increased. During the application of the first cyclic moment, the internal pressure increased slowly from $5.0 \mathrm{MPa}$ (725 psi) (see Fig. 2) (point 1.5) to a maximum pressure of $6.35 \mathrm{MPa}$ (921 psi) (point 24) and then down to a pressure of $6.27 \mathrm{MPa}$ (909 psi) (point 26). The depressurization from $0.27 \mathrm{MPa}$ (909 psi) to $1.41 \mathrm{MPa}$ (204 psi) generated an approximately linear response as shown by points 26 to 27 in the figures. Again the pressure did not decrease to zero.

The second cyclic moment of $\pm 2234 \mathrm{~N}-\mathrm{m}(19,773$ in.-1b) was applied to the model for two complete cycles as shown by the points 28 to 29 in the figures. The model shook down in these two cycles. During this cyclic moment loading, the pressure decreased from $1.41 \mathrm{MPa}$ (204 psi) to $1.19 \mathrm{MPa}(173 \mathrm{psi})$. At the end of the test the internal pressure was $1.15 \mathrm{MPa}$ (166 psi) at point 30 in the figures.

In Figs. 13 through 16, the first pressurization and the first and second moment loadings were linear (see points 1 through 13 ). The second pressurization to $5.0 \mathrm{MPa}(725 \mathrm{psi})$ gave an elastic-plastic response 
(points 14 to 15). The initial step of the first cyclic moment of \pm 1875 $\mathrm{N}-\mathrm{m}$ (16,593 in.-1b) also was nearly linear (points 16 through 22). However, the next step of this cyclic moment generated a great deal of plastic response. The second step as well as the next three moment-strain cycles are shown between points 22 and 25. Again the structure tends to shake down as the moment-strain cycles become smaller and the number of cycles is increased. Recall that the internal pressure increased slowly from $5.0 \mathrm{MPa}$ (725 psi.) to $6.35 \mathrm{MPa}$ (921 psi) and back down to $6.27 \mathrm{MPa}$ (909 psi) during the application of this cyclic moment. The depressurization from $6.27 \mathrm{MPa}$ (909 psi) to $1.41 \mathrm{MPa}$ (204 psi) generated an approximately linear response as shown by points 26 to 27 in the figures. Again the pressure did not decrease to zero.

The second cyclic moment of $\pm 2234 \mathrm{~N}-\mathrm{m}$ (19,773 in.-1b) was applied to the structure for two complete cycles, and the structure shook down in these two cycles as shown bȳ the points 28 lu 29 in the figurcc.

\section{DT.SCUSSION OF RESULTS}

The room-temperature structural test results presented here for a nozzle-to-sphere test exemplity the basic fearures of eldstic-plastic behavior for a relatively complex load histury. Because of this and because the nozzle-to-sphere attachment is one of the simplest componenttype tests, the results should be ideally suited for benchmark problem calculations.

Although the test data that have been presented are intended lu be used primarily as benchmark problem results for comparison with inelastic predictions, an exdmination of the test data alone reveals several important characteristics of inelastic behavior. Figures 9 through 16 present the load-strain responses and indicate the hardening effects that prinr plasticity has on subsequent plasticity. Consider points 16 through 25 specifically; each subsequent cycle produces less plasticity than the prior cycle. The cyclic hardening in the circumferential and meridional directions differs in that the subsequent hardening is generally greater in the circumferential direction. The behavior between points 28 through 
29 showing the second cyclic moment further illustrates the hardening effect of prior plasticity because the nozzle-to-shell attachment shakes down in two cycles.

One final and important point should be made relative to the interpretation of inelastic benchmark calculation results. The correlation of analytical predictions with experimental results for inelastic problems is by no means a straightforward procedure. Unlike the elastic case, where exact agreement can theoretically be expected and strived for, there will always be differences between predicted and measured inelastic behavior. This is because carefully controlled inelastic tests are difficult to perform, accurate measurements are difficult to make, and inelastic material behavior is a highly complex phenomenon consisting of processes and interactions that defy complete understanding and exact description. The constitutive equations that are likely to be used represent only first approximations to the descriptions of inelastic behavior. Thus, rather than exact quantitative predictions, inelastic analyses qualitatively predict the basic characteristics or the essential features of inelastic response.

\section{ACKNOWLEDGMENTS}

The authors acknowledge with appreciation the contributions to this study of several individuals at Oak Ridge National Laboratory. S. J. Claiborne instrumenter the model and hclped to peifurm the test; J. A. Hawk helped design the control system and helped with the instrumentation; and D. T. Godwin was responsible for converting the recorded test data to usable figures.

\section{REFERENCES}

1. Pressure Vessels and Piping: Verification and Qualification of Inelastic Analysis Computer Programs, American Society of Mechanical Engineers, G00088, 1975.

2. J. M. Corum, M: Richardson, and J. A. C1inard, EZevated-Temperature Benchmark Tests of Simply Supported Becoms and Circular Tlates Slibjoctod to Time-l'arying Luudirlys, ORNL-5301 (September 1977). 
3. R. C. Gwaltney et al., "Nozzle-to-Sphere Model Tests and Analyses," High-Temperature Stmuctural Design Progrom Semiannual Prog. Rep. June 30, 1977, ORNL-5339 (to be published). 
Appendix A

ELASTIC TEST OF THE NOZZLE-TO-SPHERE MODEL

In order to verify proper functioning of the loading mechanism, comparisons between experimental and analytical results were made for elastic pressure only and moment only loadings. The calculated and experimental results are shown in Figs. A.1 to A.3. All the calculated results were obtained using the STATIC $^{1}$ shell code.

The results for the different segments of the model are shown separately. The distances in the figures are referenced to the midsurface intersections of the individual segments; the nozzle and transition fillet are referenced from the intersection of the nozzle fillet and the transition fillet, and the distances for the spherical portion are referenced to the intersection between the transition fillet and the sphere. Exper1mental data were obtained from gages mounted along the four axial or meridional lines $90^{\circ}$ apart. The gages were the same as described in the report and shown in Fig. 7.

An examination of Figs. A.1 through A. 3 shows good agreement between the theoretical and experimental results. In Fig. A.1, which contains the comparisons for pressure loading, all the experimental data points from the four gage lines are plotted since the loading is axisymmetric. In Figs. A. 2 and A.3, which contain the comparisons for the moment loading, only gages along one gage line are plotted since this load is nonsymmetric. 'l'he good comparisons show that the loading mechanism functioned correctly for the static: elastic loads.

1. A. Kalnins, Static, Free Vibration, and Stability Analysis of Thirl Elastic Sheils of Revolution, Air Force Flight Dynamics Laboratory, Wright-Patterson Air Force Base, Ohio, AFFDL-TR-68-144 (March 1969). 

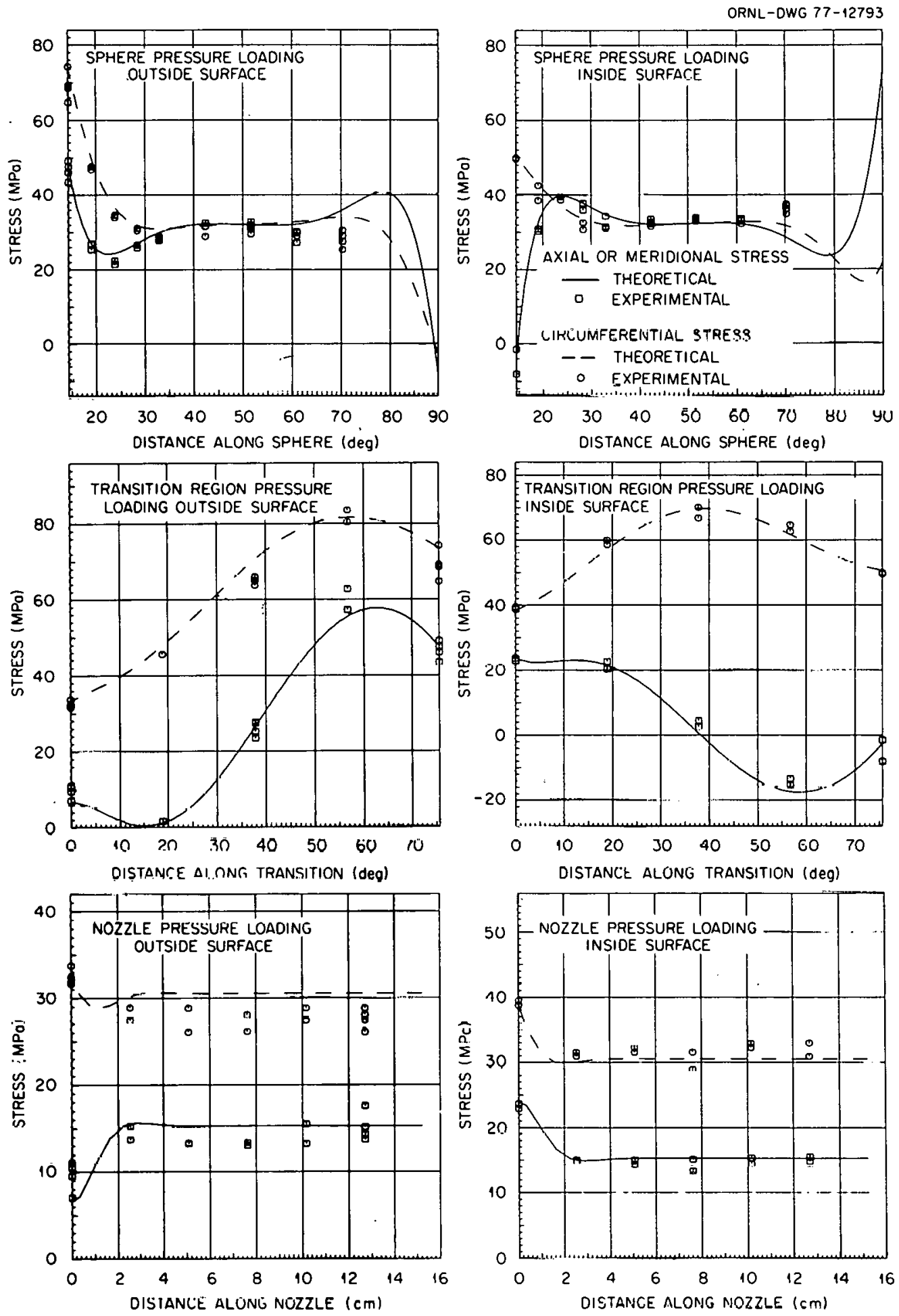

Fig. A.1. Calculated and experimental elastic stress distributions for internal pressure of $1.72 \mathrm{MPa}$ (250 psi). 

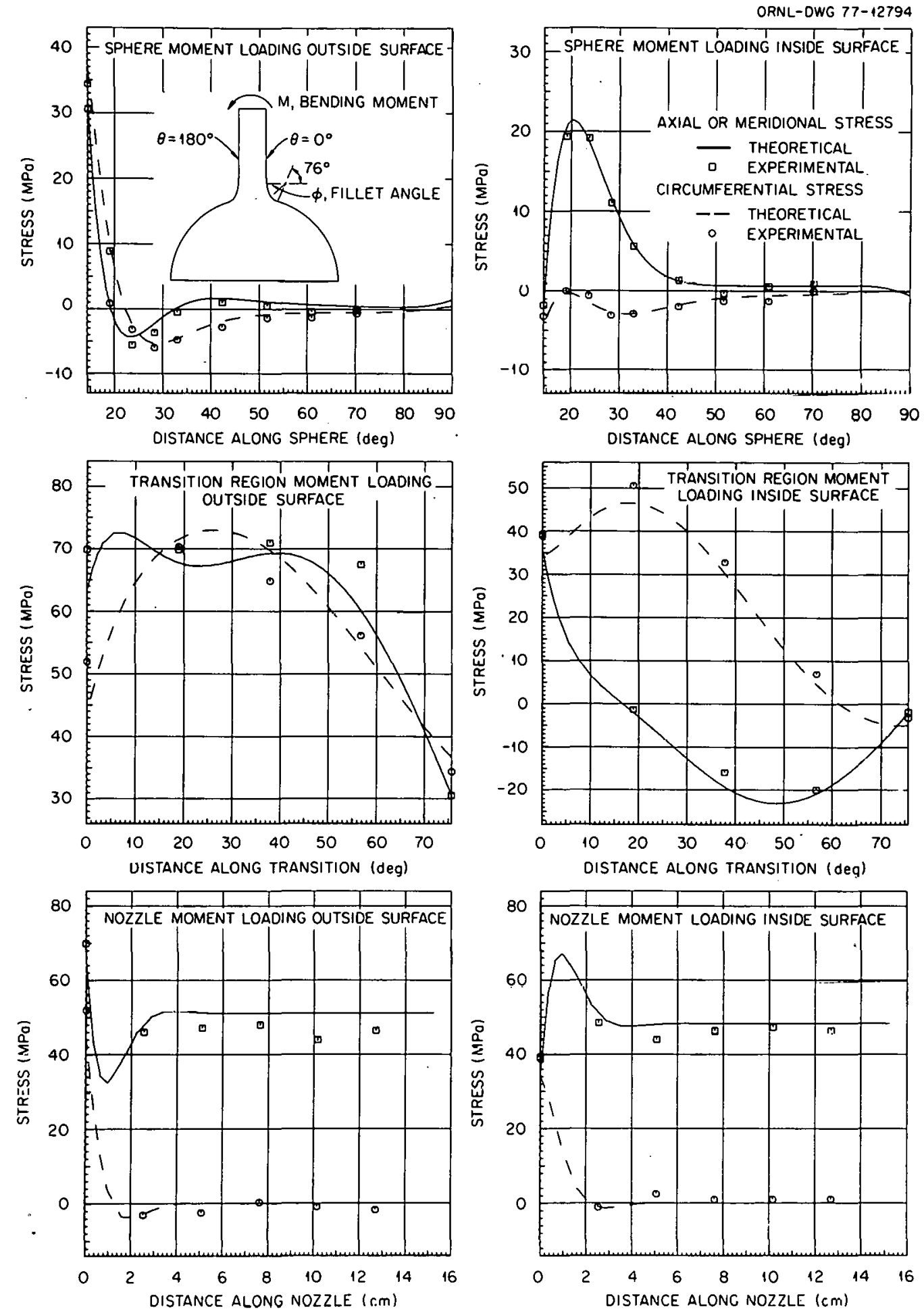

Fig. A.2. Calculated and experimental stress distributions along the $0^{\circ}$ plane for a bending moment of $1130 \mathrm{~N}-\mathrm{m}(10,000$ in. $-1 \mathrm{~b})$. 

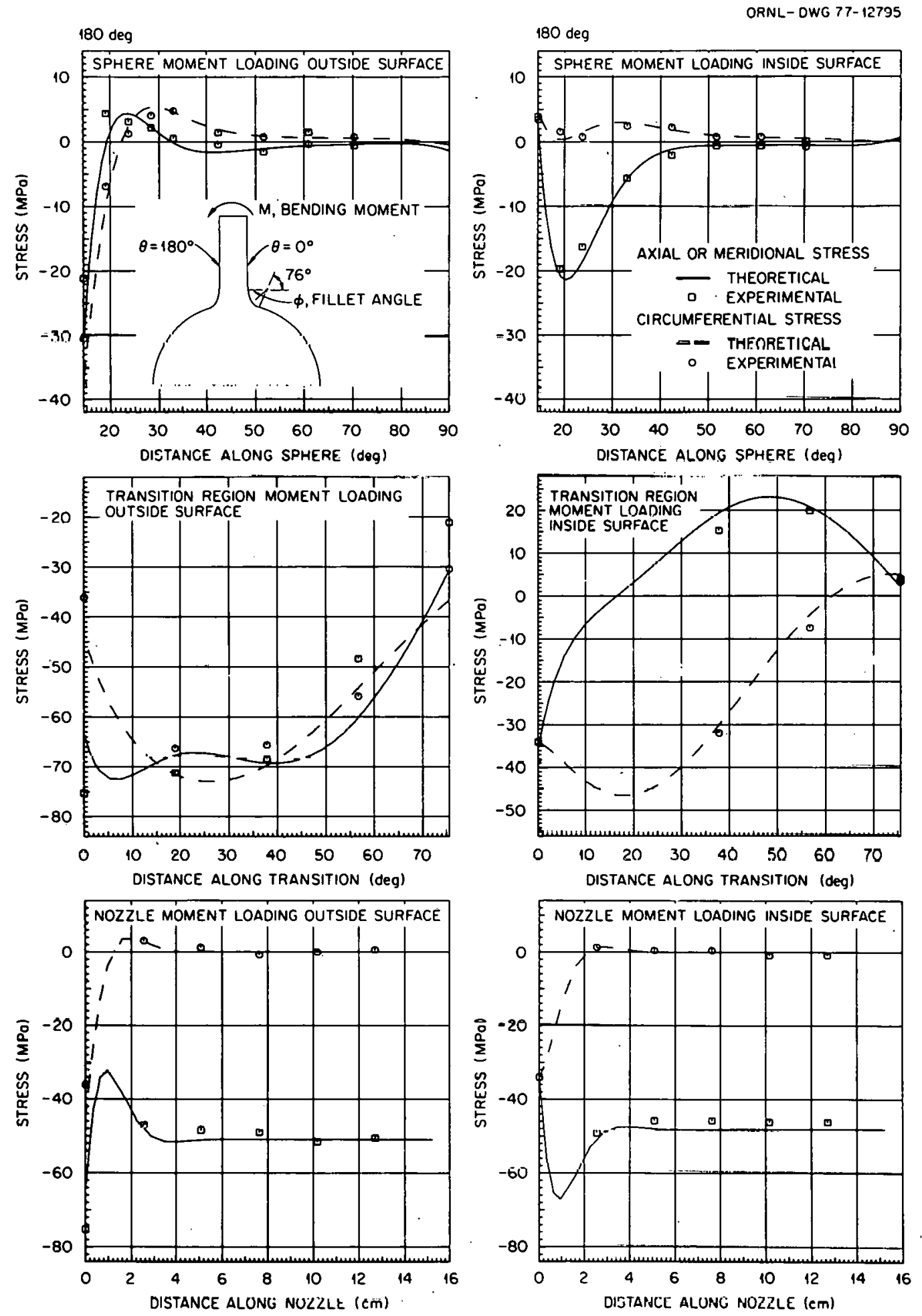

Fig. A.3. Calculated and experimental stress distributions along the $180^{\circ}$ plane for a bending moment of $1130 \mathrm{~N}-\mathrm{m}(10,000$ in.-1b). 
ORNL/TM-6170

Dist. Category UC-79, $-79 \mathrm{e},-79 \mathrm{~h},-79 \mathrm{k}$

\section{Internal Distribution}

1-3. R. L. Battiste

4. J. J. Blass

5. S. E. Bolt

6. C. R. Brinkman

7. J. W. Bryson

8. J. H. Butler

.9. J. P. Callahan

10. J. A. Clinard

11. C. W. Collins

12. S. J. Chang

13. W. E. Cooper

14-18. J. M. Corum

19. T. J. Delph

20. W. G. Dodge

21. J. R. Ellis

22. W. L. Greenstreet

23. A. G. Grindell

24-38. R. C. Gwaltney

39. W. O. Harms

40. J. F. Harvey

41. R. L. Huddleston

42. S. K. Iskander

43. P. R. Kasten

44. R. T. King

45. K. L. Klueh

46. Milton Levenson

47. R. E. MacPherson

48. W. J. McAfee
49. H. E. McCoy

50. H. C. McCurdy

51. J. G. Merkle

52. S. E. Moore

53. E. T. Onat (consultant)

54. P. Patriarca

55. H. Postma

56. C. E. Pugh

57-59. M. Richardson

60. D. N. Robinson

61. G. C. Robinson

62. W. K. Sartory

63. Myrtleen Sheldon

64. V. K. Sikka

65. G. M. Slaughter

66. J. E. Smith

67. J. P. Strizak

68. R. W. Swindeman

69. H. E. Tramme11

70. D. B. Trauger

71. G. D. Whitman

72. G. T. Yahr

73. H. C. Young

74. Patent Office

75-76. Central Research Library

77. Y-12 Document Reference Section

78-80. Laboratory Records Department

81. Laboratory Records (RC)

\section{Subcontractors}

82. H. Armen, Jr., Grumman Aerospace Corp., Bethpage, NY 11714

83. C. E. Jaske, Battelle-Columbus Laboratories, Columbus, OH 43201

84. W. J. O'Donnell, O'Donnell and Associates, Pittsburgh, PA 15232

85. D. H. Pai, Foster-Wheeler Energy Corp., Livingston, NJ 07029

86. C. C. Schultz, Babcock and Wilcox Co., P.0. Box 835, Alliance, $\mathrm{OH} 44601$

\section{External Distribution}

87-88. Director, Division of Reactor Research and Technology, Department of Energy, Washington, D.C. 20545

89. Director, Reartor Divisinn, ORO

90. Research and Technical Support Division, ORO 
91-344. Given distribution as shown in TID-4500 under categories UC-79, $-79 e,-79 h,-79 k$ 